$C 55.8: M 33$

Guide to

Information on

Research in Marine,

Science and

Engineering

3

2x- $\quad$ - $x$

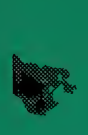

4

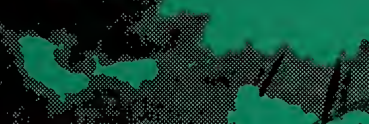

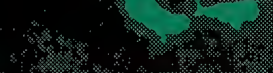
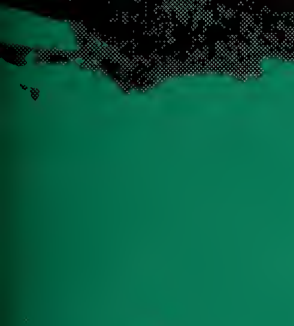

.

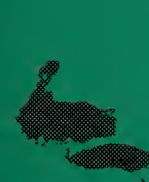

$\sin$

(2),

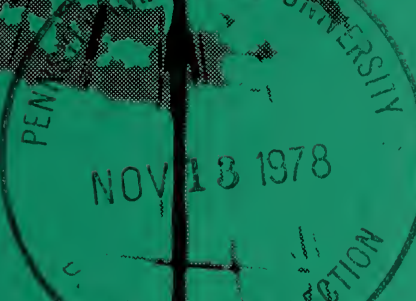

(1) 2 " ? ?
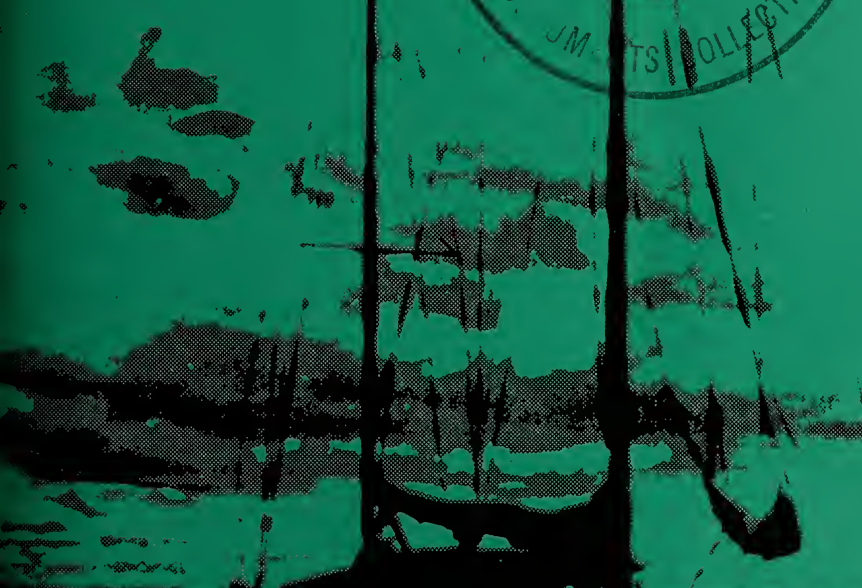

11. 00101.1

$x^{2}+x+\infty$

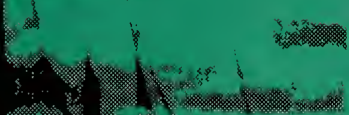

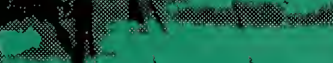

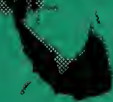

I.
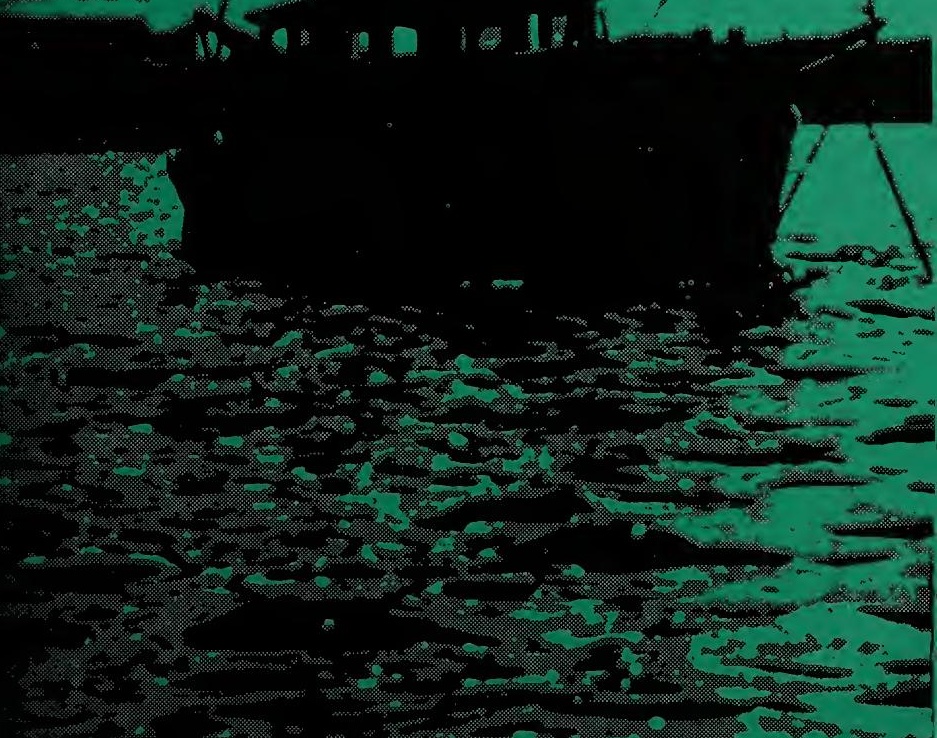
Mention of private information service groups in this publication is for purposes of identification only. This does not constitute endorsement of these groups by the U.S. Department of Commerce or National Oceanic and Atmospheric Administration and should not be used in advertising in any manner. 


\section{Guide to Information on Research in Marine Science and Engineering}

Rockville, Md.

October 1978

Prepared by:

U.S. DEPARTMENT OF COMMERCE

National Oceanic and Atmospheric Administration Office of Ocean Engineering 


\section{FOREWORD}

This Guide to Information on Research in Marine Science and Engineering is a revision and expansion of the 1977 Guide. It should improve user ability to obtain access to ongoing research information as well as a much greater range of federal and non-federal data and information bases. This brochure also has descriptions of the ocean research and development responsibilities of several federal agencies, including source contacts for further assistance.

User comments on this brochure are welcome and should be addressed to:

Director

Office of Ocean Engineering

National Oceanic and Atmospheric

Administration

Rockville, Maryland 20852 


\section{CONTENTS}

AGENCY PROGRAMS IN MARINE

SCIENCE AND ENGINEERING ........ 1

Department of Commerce ........... 1

National Oceanic and

Atmospheric Administration .......... 1

Maritime Administration ........... 3

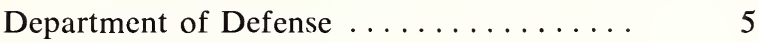

Department of the Navy ........... 5

U.S. Army Corps of Engineers . . . . . . . 6

Defense Documentation Center ...... 7

Department of Health, Education,

and Welfare ................. 10

Public Health Service ............ 10

National Institutes of Health . ....... 10

Food and Drug Administration ...... 11

National Institute for Occupational

Safety and Health ........... 11

Department of the Interior . . . . . . . . . 12

Bureau of Land Management ......... 12

U.S. Geological Survey ... . . . . . . . . . 12

Bureau of Mines ............... 12

Ocean Mining Administration ........ 13

Bureau of Reclamation ............ 13

Office of Water Research

and Technology .............. 13

U.S. Fish and Wildlife Service ........ 14

National Park Service ............... 14

Bureau of Outdoor Recreation ......... 14

Bureau of Indian Affairs ............ 14

Department of State .............. 15

Department of Transportation ............. 15

U.S. Coast Guard .............. 15

Department of Energy ............. 16

Environmental Protection Agency ........ 18

National Aeronautics and

Space Administration ... . . . . . . . 20

National Science Foundation .......... 21

Oceanography Project Support ........ 21

International Decade of

Ocean Exploration ............. 21

Oceanographic Facilities and Support ... 21

Smithsonian Institution ............ 22

Investigations of Marine Shallow

Water Ecosystems ............ 
Scientific Event Alert Network ........ 22

Smithsonian Oceanographic Sorting Center 22

Chesapeake Bay Center for

Environmental Studies ........... 22

Smithsonian Tropical Research Institute . . 22

Fort Pierce Bureau ............... 23

ACCESS TO MARINE SCIENTIFIC AND

TECHNICAL DATA AND INFORMATION 23

Current Research Information ......... 23

Smithsonian Science Information

Exchange, Inc. .............. 23

Custom Searches .............. 24

Selective Dissemination of Information . . 24

Investigator or Accession Number Search . 24

SDC/SSIE On-Line Search Service ..... 24

Research Information Packages ....... 25

Environmental Data and Information ..... $\quad 32$

National Technical Information Service . . 32

Oceanic and Atmospheric Scientific

Information System ........... 33

Environmental Data Index .......... $\quad 34$

Regional Coastal Information Centers ... 34

EDIS Data Centers .............. 35

National Oceanographic Center ..... $\quad 35$

National Climatic Center .......... $\quad 36$

National Geophysical and Solar-

Terrestrial Data Center ......... 36

Non-Government Sources of Information . . 37

Information Industry Association . . . . . . 37

Lockheed Information Services ........ 37

Raytheon Service Company . . . . . . . . 37

Marine Information and Advisory Service $\quad 38$

SUBJECT TERMS IN MARINE SCIENCE

AND ENGINEERING COMPILED BY

THE SMITHSONIAN SCIENCE

INFORMATION EXCHANGE ....... 


\section{AGENCY PROGRAMS IN MARINE SCIENCE AND ENGINEERING}

\section{DEPARTMENT OF COMMERCE}

\section{National Oceanic and Atmospheric Administration}

Marine research and development within the National Oceanic and Atmospheric Administration (NOAA) covers a wide spectrum of activities in biology, ecology, physical oceanography, and systems development that contribute to NOAA's goal of ensuring wise development and rational conservation of ocean resources for the economic and social good of the nation.

Studies of marine life distribution and the effect of pollutants and other environmental stresses upon their habitat are given special emphasis. These studies, conducted by NOAA laboratories, contractors, and universities, deal with commercial and sports fishing areas, conservation of endangered species, microconstituent research, environmental impact assessment, and overall management of living marine resources. Included are programs designed to assure that only safe and wholesome fishery products reach the consumer. Important research is being carried out by a network of national Sea Grant institutions and state agencies, which receive matching federal grants to seek solutions to problems relating to the management and use of marine resources, and marine technology transfer.

Considerable emphasis is also being placed on detailed physical and biological analyses of large marine ecosystems, such as the New York Bight and Puget Sound, to provide ecological data needed for balanced use of the marine environment and its resources. Assessing the impact of ocean dumping and waste disposal on marine ecosystems is a vital part of research conducted by several laboratories, which includes related studies of ocean circulation, coastal upwelling, and tides.

The impact of the development of nonliving resources, such as gas, oil, and minerals on coastal and deep ocean areas is being studied in an attempt to establish baselines from which environmental changes can be measured and to predict future environmental impact in order to avoid irreversible damage to marine life. Also, 
through investigation of the air-sea interface vital knowledge is being obtained for weather forecasting and for warning announcements of floods, waves, tides, and hurricanes to all segments of the population.

These activities are supported by an oceanographic research and survey fleet that also participates in extensive mapping and charting; aircraft; ocean engineering instrumentation systems, buoys, and manned underwater submersibles; and satellite and remote sensing devices, including visible, infrared, and microwave radiometers, as well as conventional instrumentation.

Major components of NOAA carrying out this research are the National Marine Fisheries Service, the Environmental Research Laboratories, the Office of Sea Grant, the National Environmental Satellite Service, the National Weather Service, the National Ocean Survey, and the Environmental Data and Information Service (formerly the Environmental Data Service).

The National Environmental Satellite Service (NESS) manages and operates the environmental satellite systems. High resolution data are used to map ocean and lake thermal gradients and lake and sea ice concentrations. NESS also uses data from Landsat and Nimbus satellites to study the color, biology, pollution, and sea state of marine areas.

The National Weather Service (NWS), through investigation of the ocean's temperature and current systems, is obtaining vital knowledge for improving weather prediction. New measurement and ocean prediction techniques are under development which will improve forecasts and warnings of coastal storm flooding, hurricanes, and ocean waves for many segments of the population.

The National Ocean Survey (NOS) conducts programs in marine science, engineering, and development to support NOAA programs in mapping, charting, oceanographic surveying and monitoring, geodesy, and vessel operation.

Most of this marine research is centered in the Office of Marine Technology (OMT) which is responsible for the design, development, test, and evaluation of marine sensing instruments, their supporting hardware, software, and associated data processing systems. In addition, OMT maintains a federal facility for oceanographic instrumentation testing and evaluation, and the development of calibration methods and test standards on a national basis. The Office of Marine Technology also assesses requirements and formulates the design of systems for collection and processing of oceanographic, 
marine meteorological and related marine environmental data.

For further information write to:

Director, Environmental Science Information Center (D8)

Environmental Data and Information Service

National Oceanic and Atmospheric Administration

Rockville, Maryland 20852

\section{Maritime Administration}

The Maritime Administration (MarAd) promotes the development, operation, and maintenance of an efficient American-flag merchant marine capable of meeting the commercial and military shipping requirements of the United States. It assists the maritime industry by promoting shipper patronage of U.S.-flag vessels, developing advanced transportation systems and shipboard equipment, evaluating ship design, training merchant marine officers, and providing financial support to American shipbuilders and operators to narrow the cost advantages enjoyed by their foreign competitors.

MarAd carries out a broad research and development program to improve the productivity and competitive posture of the U.S. merchant marine through technological innovations. The program follows two parallel paths that correspond to the structure of the maritime industry itself. Advanced Ship Development studies deal with the technologies of ship building, ship machinery, and nuclear merchant ships. Advanced Ship Operations projects deal with ship and cargo operations generally, ship control technology, and navigation and communication.

Basic research is done on the classical naval architecture technologies of propulsors, structures, and hydrodynamics. Emphasis is on advanced propellor designs and materials to achieve improved efficiency. For example, a highly skewed propellor has been developed which allows the application of higher horsepower with little or no vibration and thus greater efficiency and reduced maintenance. Investigations are conducted, in cooperation with other agencies and the National Academy of Sciences, to determine the effects of sea loads and vibrations on ship structures. Hydrodynamics projects are aimed at improving the efficiency of moving vehicles through the sea with emphasis on powering technology, speed, and maneuvering characteristics and limitations. Further exploratory research involves hu- 
man factors, ship automation and communications, and energy and environmental research.

An important tool developed for the in-house work on maritime research is the Computer Aided Operations Research Facility (CAORF). At this unique simulator, built around a typical ship wheelhouse and control center and with computer-generated images of the changing scene projected on a wide, cylindrical screen, simulated ships of all types can be maneuvered through any harbor configuration or environmental and traffic situation in real time. Many of the tests at CAORF enable study of human reactions to complex problems, new equipment, passage through dangerous channels, and any number of other conditions to improve the safety and productivity of ship operations.

For further information write to:

Assistant for Program Development

Office of Commercial Development

Maritime Administration

14th and E Streets, N.W.

Washington, D.C. 20230

The Maritime Administration's Maritime Research Information Service (MRIS), operated for the U.S. maritime industry, is designed to provide comprehensive information on proposed, ongoing, and completed research and development projects and to technical reports and journal articles. In addition to U.S. research information, the data files as of 1977 also contain abstract information from the British Ship Research Association and the Ship Research Institute of Norway ("Ship Abstracts").

"MRIS Abstracts" is published and distributed every six months and contains all the information collected during that period, as well as a key word and authors index, and a publisher/performing/funding agency list.

The "Current Awareness Service" is published monthly, and, in addition to the information collected during the period, contains a list of meetings and conferences, citations of transportation articles, and reports prepared in cooperation with the Transportation Center, Northwestern University.

MRIS also offers computerized literature searches of the data files to compile selected bibliographies with abstract, author, source of the document, and any of the other information in the system. 
For further information write to:

Maritime Research Information Service

Transportation Research Board

National Academy of Sciences

2101 Constitution Avenue, N.W.

Washington, D.C. 20418

\section{DEPARTMENT OF DEFENSE}

\section{Department of the Navy}

Marine research and development designed to meet Navy requirements include a variety of projects, among them the following: improvement in tidal predictions and better understanding of energy transfer in coastal processes; sea-state observations through correlation of electromagnetic backscatter with wave spectra; environmental support for deep ocean operations through enhanced capabilities for remote data gathering; increased understanding of the dynamics of deep ocean mooring systems for buoyed oceanographic sampling packages; use of SEASAT in the study of surface oceanographic conditions; marine biological research dealing with boring and fouling organisms and animals that affect acoustic transmission in the ocean; identification of communities in the deep scattering layer and correlation of the location of the layer with physical parameters; and determination of the contribution of marine mammals to oceanic ambient noise.

In ocean engineering, projects are underway to expand work in the deep ocean by manned and unmanned submersibles and by divers. The Large Object Salvage System, begun in 1965 and nearing completion, makes it possible to salvage objects weighing up to 1,000 tons from depths down to 850 feet. Another project designed to extend this capability to 20,000 feet has begun. In biomedicine, deep nitrogen-oxygen saturation chamber exposure tests are being made to define limits of human performance under nitrogen narcosis. Decompression principles are being studied for both shallow dives from nitrogen-oxygen exposures to 100 feet and shallow and intermediate depth excursions while breathing heliumnitrogen-oxygen tertiary mixtures. An Environmental Health Effects Laboratory for investigating diver physiology to simulated depths of 3,400 feet is scheduled for completion in 1977. 
For further information write to:

Office of the Oceanographer of the Navy

Code N45

Hoffman Building II

200 Stovall Street

Alexandria, Virginia 22322

\section{U.S. Army Corps of Engineers}

The marine research and development programs of the U.S. Army Corps of Engineers pertain to the Corps' civil works responsibility in the coastal zone and the nearshore ocean areas, with results primarily applicable to shore protection and navigation studies, as well as to the understanding and dissemination of knowledge concerning coastal processes and nearshore oceanography.

Specific programs include coastal hydraulics, sediments, and structures; structure-sediment-hydraulics interactions; coastal ecology, beach nourishment techniques; systems for sand-bypassing; and navigation channel dimensions and alinements. Results of these programs, and of the many subtasks within them, are disseminated in the form of research reports, papers, technical memoranda, and regulations.

A number of congressionally directed studies are also being carried out. The dredged material research program, for example, provides definitive information on the environmental impact of dredging and dredged material disposal operations. Another objective is to develop technically satisfactory, environmentally compatible, and economically feasible dredging and disposal alternatives, with consideration given to dredged material as a manageable resource. Additional areas of research include island and marsh habitat construction, mariculture involving dredged materials, and tractability of consolidated fine materials.

In the Chesapeake Bay Study, a comprehensive study of the Bay waters and associated land resources, a physical model, 14 acres in area, is being used to aid in the investigation of management alternatives for the use of the Bay's resources.

Two laboratories are responsible for most of the Corps' research development activities: The Coastal Engineering Research Center, Fort Belvoir, Virginia; and the Waterways Experiment Station, Vicksburg, Mississippi. The former is in charge of conceiving, planning, conducting, and publishing the results of research and data collection in coastal engineering and nearshore oceanography, including shore and beach erosion con- 
trol; flood and storm protection; the location, layout, design construction, operation, and maintenance of harbor, coastal, and offshore structures; navigation improvement; and recreation. The Center is equipped with wave tanks and coastal processes basins, and has full-scale field facilities on both the Atlantic and Pacific coasts.

The Waterways Experiment Station, the Corps' main research, testing, and development facility, supports the civil and military missions of the Chief of Engineers and other federal agencies through the operation of a complex of laboratories in the fields of hydraulics, soil mechanics, concrete, engineering geology, rock mechanics, pavements, vehicle mobility, environmental relationships, aquatic weeds, water quality, dredge materials, and excavation. Marine research is conducted mainly in hydraulics, soil mechanics, and environmental research laboratories. In particular, the Hydraulics Laboratory deals with river, tidal, waterwave, and structural hydraulics problems, and carries out basic and applied research, as well as supporting engineering design, through theoretical and mathematical analysis, laboratory and field experimentation, and field measurements.

For further information write to:

Chief of Engineers (DAEN-RDC)

Department of the Army

Washington, D.C. 20314

\section{Defense Documentation Center}

The Defense Documentation Center (DDC), a field activity of the Defense Logistics Agency of the Department of Defense, makes available from one central depository thousands of research and development reports produced each year by U.S. military organizations and their contractors. The Center also operates computer-based data banks of management and technical information. Technical Report Program. DDC collects, processes, announces, retrieves, and supplies reports of formally recorded technical information in virtually all areas of science and technology. The Center's technical report collection totals more than 1,200,000 titles. About 900,000 of these are under computer control for quick retrieval. More than 2,400 documents which deal with ocean currents are in the report collection; more than 1,500 reports pertain to ocean bottom topography. Every other aspect of oceanography is covered within the collection.

DDC announces the availability of documents it accessions through its own announcement publications and 
through announcement media of the Department of Commerce. Newly accessioned classified or limiteddistribution documents are announced every other week in the DDC Technical Abstract Bulletin and its Indexes. Unclassified documents available to the public are processed by the National Technical Information Service and listed in the Government Reports Announcements and Indexes.

Organizations registered for DDC services may request copies of the technical reports in either full-size or microfiche. The Center assesses a $\$ 4$ service charge for paper copies of technical reports. A charge of 95 cents is made per title for microfiche copies. Reports provided under the Center's Automatic Document Distribution program are supplied at 35 cents each.

Authority to provide a document is determined by the security classification of the report and by any release limitations imposed by the source of the report. Although only registered organizations can obtain documents from DDC, unclassified reports without distribution limitations are available at a fee to anyone through the National Technical Information Service, 5285 Port Royal Road, Springfield, Virginia 22161.

DDC report bibliographies provide selected references in response to specific requests for information relating to actual work problems. A request can be expressed in various ways such as subject matter, organizational sources, contract numbers, personal authors, and any other logical frame of references. Each page of the bibliography contains the descriptive and analytic information on a single page.

No charges are assessed for bibliographies, and users are encouraged to use this service. If a user should receive a bibliography that is not satisfactory, the request should be rephrased and resubmitted.

The Research and Technology Work Unit Information System is designed to provide scientists, engineers, and managers in the federal R\&D community with an automated rapid retrieval capability for documents of completed research and development; it is also a central source of management and status information on Defense-sponsored $R \& D$ in progress.

Essentially, the purpose of the R\&T work Unit Information System is to provide the means to determine quickly who is doing what research, when, where, and how. About 25 data fields are used to describe each work unit, the logical segment of an R\&D effort chosen by local management for the purposes of technical control. In addition, the summary provides for descriptions of the technical objectives, approaches to be taken, and 
the progress made on the various efforts. This information is computer-stored to permit retrieval in a wide variety of logical combinations of the data elements.

The system helps R\&D managers identify on-going efforts in any scientific discipline, area, or technology; coordinate current efforts; and determine whether specific areas of endeavor adequately reflect $R \& D$ policy guidance. Scientists and engineers may use the system to determine the approach and current status of technical efforts related to their own tasks, to identify scientists and engineers working in areas of similar technical interests, and to periodically review progress statements in pertinent work units.

Data are available to Defense components and other federal agencies, in a variety of formats, such as statistical summaries, tabulations, and complete or partial printouts of selected resumes. Limited access to the data bank is available to contractors and grantees of federal agencies through the use of a single, fixed-format report. Searches of the data bank are free.

The R\&D Program Planning Data Bank, also operated by DDC, contains descriptions of R\&D projects planned by DoD organizations. This information is available only to the Director of Defense Research and Engineering and to other DoD managers for use in reviewing the proposed R\&D efforts of Defense organizations. Searches of this data bank are also free.

The Independent Research and Development (IR\&D) Data Bank contains descriptions of R\&D efforts being performed by contractors who are not fully funded by the Department of Defense. The purpose of this collection is to improve communications between Department of Defense scientists and engineers and their counterparts in industrial organizations.

Searches of the IR\&D data bank are available to the Director of Defense Research and Engineering, to registered DoD activities, and to certain offices within the National Aeronautics and Space Administration. Searches of this data bank also are free.

DDC operates the Defense RDT\&E On-Line System, which extends to certain major user organizations the capability of individually querying the four major data banks operated by the Center. These users have direct access to the DDC computers through remote terminals established at their facilities. About 90 remote terminals were operating at the end of 1977. 


\section{DEPARTMENT OF HEALTH, EDUCATION, AND WELFARE}

\section{Public Health Service}

The Public Health Service participates in the federal marine science and engineering effort by (1) conducting research aimed at an understanding of factors in the marine environment that have an adverse effect on human health, and investigating the mechanisms through which that toxicity is expressed; (2) using marine organisms as study objects in research to broaden the knowledge base of science underlying medical technology and practice; and (3) making its research findings available and providing technical assistance, training, and consultation to regulatory agencies, industry, and the general public.

At the National Institutes of Health, toxic factors in the marine environment are the particular concern of the National Institute of Environmental Health Sciences, with principal laboratories in Research Triangle, North Carolina, and satellite laboratories on Mount Desert Island, Maine, and at Marineland, Florida. Scientists of this Institute, and Institute grantees, are concerned with the effects of pollutants and toxic chemicals on the ecology of rivers, estuaries, and the sea, with particular reference to their potential for causing human disease when affected marine organisms are used as food. Other research fostered by the National Institute of Environmental Health Sciences deals with the health effects of toxins of marine origin, such as those of dinoflagellates and jellyfish.

The use of marine organisms as models for the study of biologic phenomena of general scientific interest pervades the basic science programs of the National Institutes of Health. At least 11 of its 15 research institutes or divisions conduct or support scientific activity in this area. Familiar examples are the use of squid axons in research on the biophysics of transmission of nerve impulses, and of fertilized sea urchin eggs in the study of embryonic differentiation. Less well-known examples are the study of the adhesive properties of barnacles, supported by the National Institute of Dental Research because such research might lead to the development of better dental restorative materials, and the maintenance by the National Cancer Institute of a registry of spontaneously occurring tumors among marine animals. The National Institute of Neurological and Communicative Disorders and Stroke maintains a year-round laboratory at Woods Hole, Massachusetts, for the study of neurophysiological phenomena in marine organisms. 
Although terrestrial plants and animals have yielded many valuable medicinal chemicals, among them penicillin, morphine, digitoxin, quinine, insulin, and heparin, the presumed potential of marine organisms as sources of therapeutically useful drugs has not been realized. The National Cancer Institute and the National Institute of Allergy and Infectious Diseases, in particular, sponsor programs of pharmacologic research in which marine species are screened for natural compounds potentially useful in the treatment of disease. Marine organisms may also yield materials which are of practical use as reagents in laboratory science. Examples are keyhole limpet hemocyanin and a lysate prepared from the amoebocytes of the horseshoe crab, both commonly used in the study of infections and immunologic phenomena in higher animals, including humans.

The National Institutes of Health sponsor research in environmental medicine, including projects of particular interest to marine scientists. National Heart, Lung, and Blood Institute grantees are active in research on the physiology of the "diving reflex," and in studies of mammalian pulmonary physiology and gas metabolism under conditions of high pressure. The Institute also sponsors studies of the use of liquids to substitute for gases in breathing, research that raises possibilities of permitting dives to great depths, and investigations of the effects of hydrostatic pressure variations on the functioning of mammalian cells. Both the National Heart, Lung, and Blood Institute and National Institute of General Medical Sciences support research on temperature regulation and thermal adaptation of diving mammals, with potential applications to diving.

The Food and Drug Administration (FDA) is responsible for assuring that marine food products shipped in interstate commerce are safe and wholesome and are properly labeled. FDA promulgates appropriate regulations, conducts inspections of marine food processors, examines seafood for contaminants, and supports projects for improving scientific enforcement methods. FDA also develops special seafood control programs with cooperating state control agencies. These activities are based upon the requirements of the Federal Food, Drug and Cosmetic Act, as amended, Public Health Service Act, and Fair Packaging and Labeling Act.

The National Institute for Occupational Safety and Health (NIOSH) of the Center for Disease Control (1) is still active on a consulting basis with the Occupational Safety and Health Administration (OSHA) concerning recent promulgated diving regulations, and (2) 
is currently preparing a RFP for a contract to study the epidemiology of divers.

For further information write to:

Office of the Chief Engineer, PHS

Parklawn Building, Room 18-42

5600 Fishers Lane

Rockville, Maryland 20857

\section{DEPARTMENT OF THE INTERIOR}

The Bureau of Land Management has responsibility for administering all surface and subsurface uses, including mineral development, of federal lands not dedicated to specific purposes. As part of that responsibility, the Bureau supports a broad range of marinerelated environmental, social, and resource research, mostly through contract, to ensure proper and safe management of the Outer Continental Shelf and the coastal zone. It also maintains data banks for the preparation of environmental impact statements concerning these land areas, as well as in support of other activities related to federal land management.

As part of its mission to examine the geologic structure and the mineral and water resources of the nation, the U.S. Geological Survey conducts and supports programs devoted to topographic mapping of coastal lands, to geological and geophysical investigations of the U.S. Continental Margins, and to collecting and interpreting data on the relationships between surface and subsurface waters of the lands and oceans. Information services particularly pertinent to marine science and engineering are provided by the agency's National Cartographic Information Center and Office of Water Data Coordination.

The Bureau of Mines conducts supply/demand analysis and mining/metallurgical research on the nonenergy metals, minerals, and materials in support of national mineral and mining policy. These functions include mineral resources and their development in the marine environments. Collection and analysis of technical-economic information on ocean mineral resource distribution, quantity, and mineral content, are sponsored by grants and contracts. These data provide input into the Minerals Availability System, a computerized data retrieval system. Oceanographic maps showing seabed mineral resource data are also prepared. The supply/demand studies, other economic analyses, and technology assessment relating to ocean mineral resource 
development are conducted by in-house and contract work. Research on the processing of ocean minerals, particularly the seabed metal-bearing nodules, is conducted in Bureau laboratories.

The Ocean Mining Administration, established by Departmental Order in 1971, has responsibility for coordination of activities in the Department of the Interior related to mining of the deep seabed beyond the limits of national jurisdiction, and acts as the principal focus of coordination on such matters with other Agencies and Departments; in addition, it serves as a focal point within the Department on matters related to the resources of the Antarctic and the surrounding ocean areas.

The Bureau of Reclamation has responsibility for the conservation, development, and use of water and related land resources in the 17 western states, and is involved, in some cases, with marine-related activities of coastal areas in the West.

A more direct role is played by the Department's Office of Water Research and Technology, which provides grants through institutes in each state for research on water-related problems, including those in coastal areas. Topics addressed include water supply, augmentation, water-quality maintenance, protection of environment, and integration of land use and water planning. The office operates the Water Resources Science Information Center, a computerized bibliographic information retrieval facility covering the literature in 10 fields of water resources: water properties; water cycle comprising precipitation, evaporation, transpiration, runoff, surface water, soil and groundwater, plant-water processes, erosion, water chemistry, and estuaries; water supply augmentation and conservation; water quantity management and control; water quality management and protection; water resources planning; resources data; engineering works; manpower and grants; and scientific and technical information.

Abstracts of the published literature and derived, reformatted products, and summaries of ongoing water resources research are machine searchable. The abstracts are published twice monthly as Selected Water Resources Abstracts (SWRA). The public can purchase publications from NTIS and has access to computer searches of the abstracts base through five network sites.

Requestors may subscribe to the abstract journal, request a computer search of the bibliographic file, and purchase publications (bibliographies and reviews) from NTIS. These services are available free to investigators 
on grant or contract to OWRT, State Water Resources Research Institutes, and to federal agencies with water responsibilities and their contractors and grantees.

For further information write to:

\section{Manager}

Water Resources Scientific Information Center

U.S. Department of the Interior

Washington, D.C. 20240

The U.S. Fish and Wildlife Service has lead responsibility within the Department for the conservation and enhancement of wildlife and "non-marine" gamefish, including all fisheries of the Great Lakes and many species of fish also found in the oceans. It manages the National Wildlife Refuge System, operates fish hatcheries, and conducts research on coastal habitats and ecosystems and on the environmental impact of natural and man-induced phenomena on shoreline and marine birds and mammals, with emphasis on endangered species.

The Department's National Park Service conducts and supports marine-related research in both the social and natural sciences to aid in management of coastal areas within the National Park System. These coastal areas offer a range of natural environments for marine investigations supported by others.

As the federal focal point for coordination of outdoor recreation programs, the Bureau of Outdoor Recreation supports research to improve these programs. It administers the Land and Water Conservation Fund, which constitutes a source of matching grants to state and local jurisdictions for research in planning and developing marine-related recreational programs and facilities. The Bureau of Indian Affairs, through grants to tribal councils and others, supports marine-related research advantageous to Indian interests.

For further information concerning research activities in marine science and engineering within the Department of the Interior write to:

Office of Marine Geology

U.S. Geological Survey

National Center 915

Reston, Virginia 22092 


\section{DEPARTMENT OF STATE}

Marine-related research conducted by, or under contract to, the Department of State is mainly concerned with economic, legal, political, and social aspects, and consists chiefly of ad hoc projects of short duration dealing with timely issues.

The Department also maintains an inventory of government-supported research related to foreign affairs, to which all federal agencies are invited to contribute and which includes marine research as it pertains to forcign affairs.

For further information write to:

Office of External Research

Bureau of Intelligence and Research

U.S. Department of State

Washington, D.C. 20520

\section{DEPARTMENT OF TRANSPORTATION}

\section{U.S. Coast Guard}

The U.S. Coast Guard's research and development effort is directed to provide research, development, testing and evaluation of equipment, techniques, systems, and materials in support of the myriad operations and regulatory programs of the service. Missions include search and rescue, icebreaking, enforcement of laws and treaties, aids to navigation, commercial vessel safety, marine environmental protection, and recreational boating safety. The productivity and performance for these mission areas includes such activities as the development of pollution spill detection, identification, and quantification methods; new procedures for the control and cleaning of oil and other hazardous substances in the coastal and Arctic regions; testing and evaluation of new marine sanitation devices; advancement of widearea surveillance systems; and new impact assessment techniques and information systems.

To meet the challenges posed by increased congestion of U.S. ports and waterways, research is being done on systematic identification and analysis of cargo, terminal facility, inspection procedures, and vessel structural and design problem areas; development of a marine safety information system; recreational boating safety education; improvement of port fire fighting equipment and techniques; and technology to minimize the environmental impact of deepwater ports. Continued expansion of marine activity in the coastal zone and 
polar regions has led to increased efforts to develop sophisticated surveillance methods and equipment to protect offshore resources, to enforce pollution and fisheries laws, to provide more effective search and rescue assistance, to facilitate waterborne transportation, and to support the regional national security needs.

In the area of aids to navigation and ocean operations, research is directed toward improved methods for positioning aids, a precision all-weather Loran-C navigation capability, system standards for audio-visual aids, development of solar energy for aids to navigation, and continued refinement of icebreaking techniques and facilities.

In addition to these direct operating program support activities, long-range projects include technology forecasting for underwater activity, feasibility studies of unmanned vehicles and underwater sensing, and development of vehicles and marine transportation requiring low energy use.

For further information write to:

Chief, Planning and Evaluation Staff Office of Research and Development

U.S. Coast Guard

Washington, D.C. 20590

\section{DEPARTMENT OF ENERGY}

In order to gain an understanding of the coastal zone environment as a complete system, the Department of Energy in 1975 (as the Energy Research and Development Administration) began supporting long-term research programs covering six geographic areas: the Southeast, the Northeast (Mid-Atlantic Bight), Pacific Northwest, Gulf of Mexico, the California Coast, and the Great Lakes. All of these programs with the exception of the Gulf Coast are underway. In addition operational programs in support of the recolonization of the Marshall Islands are carried out in the Pacific. Research activities include the following:

Distribution and dispersion of trace metals from rivers through estuaries and onto the continental shelf and effects of air pollutants on coastal ecosystems.

Processes that trigger the production of microscopic plant life, which is the first step in the food chain, in order to assess potential effects of energy developments. 
Influence of the Gulf Stream and winds on current patterns to determine the transfer of pollutants and nutrients along the continental shelf.

Movement of plutonium and tritium in coastal waters and resulting concentrations in marine life, and developments of a computer model to help predict future effects of energy development.

Microbial, invertebrate, and fish populations, and the movement of trace elements and radionuclides in the estuaries and coastal waters near Beaufort, North Carolina.

Basic biological processes that affect the survival of plant and animal communities on the continental shelf to assess effects of oil spills and releases from power plants on these processes.

In addition the Department's Division of Solar Energy is working on marine-related energy conversion technology, particularly ocean thermal energy conversion (OTEC) to harness thermal gradients between surface and deep ocean water. As part of the OTEC program, heat exchangers are being developed at laboratory and hench scales preliminary to ocean testing. For bioconversion, experiments in kelp mariculture are underway; in wind energy conversion, studies of offshore windmills are beginning; and technological assessment of other ocean energy options is in process, especially as related to waves, tides, and salinity gradients.

For further information write to:

Marine Science Program

Environmental Programs

Division of Biomedical and Environmental Research

U.S. Department of Energy

Washington, D.C. 20545

The Department of Energy/Fossil Energy programs relative to Marine Research are or have been:

The Seafloor Earthquake Measurement System (SEMS) will be used to reliably and cost-effectively gather earthquake information in the seismically active areas of the Outer Continental Shelf (OCS). Improvements on the state-of-the-art will include ease of installation and data retrieval, remote operations and long life (Sandia Labs). 
The "OCS Analytical Model" represents the processes involved in developing the oil and gas reserves of the Outer Continental Shelf (SDC/MRI).

The three volume "Offshore Data Sources and Contents" identifies data sources and data base contents relevant to offshore oil and gas development (exploration, development, production, transportation and onshore impact) (SDC/MRI).

The "Users and Users' Information" identifies the user and users' need for information relevant to frontier offshore oil and gas resource development (SDC/MRI).

The "Acceleration of Outer Continental Shelf (OCS) Oil and Gas Development" tested a data base system for the scientific analysis and display of environmental data (GURC).

\section{ENVIRONMENTAL PROTECTION AGENCY}

The marine research program of the Environmental Protection Agency provides the data base essential to developing guidelines, water quality standards, pesticide registration, ocean discharge criteria, and effluent standards for toxic and hazardous materials. The scientific validity of the Agency's criteria and standards is essential. Unreasonably stringent environmental quality standards would place an intolerable economic burden upon municipalities and industries but inadequately protective standards would permit environmental degradation.

Marine research activities are conducted at three laboratories located in Corvallis, Oregon; Narragansett, Rhode Island; and Gulf Breeze, Florida. Emphasis is given to research on ocean disposal (dumping and outfalls), petroleum and petroleum products, pesticides, carcinogens, thermal pollution, anti-fouling agents and disinfection, complex wastes, and ecosystems dynamics.

Research at the Corvallis Environmental Research Laboratory is directed toward ocean outfall discharges and non-point source pollutants. The objectives of this research include the development of assessment techniques and methods, the determination of ecosystem effects, and the development of the scientific base necessary to regulate ocean outfall and non-point discharges for optimal ecosystem protection. Mathematical and simulation modeling for predicting pollutant dynamics and the potential for ecosystem alterations is an integral part of this research effort. Other research involves wetlands and determination of the relative "health" of marine ecosystems. 
Research at the Narragansett Environmental Research Laboratory responds directly to a legislative mandate to develop marine water quality criteria as a defensible decision base for setting and enforcing marine water quality standards. Additional research seeks to assess the environmental impact of ocean dumping of materials such as dredge spoils, sewage sludge, and industrial wastes. Other programs examine the effects of petroleum and petroleum products discharged into the marine environment, and the risks associated with exposure to pollutants.

At the Gulf Breeze Environmental Research Laboratory research is conducted on the ecological effects of pesticides and other synthetic organic compounds on marine and estuarine organisms and ecosystems. Studies are also conducted to determine the pathways, biological effects, and fate of hazardous organic and inorganic pollutants in estuarine ecosystems, simulated as well as in natura. Research concerned with the effects of toxicants on marine and estuarine species at the cellular, tissue, organism, and ecosystem level is ongoing and integrated into the overall research effort. Research is also conducted on dredge materials and disinfection.

The recently established Evironmental Research Information Center, Cincinnati, is the central contact point for obtaining research information including Technology Transfer publications. ERIC's active information transfer program interprets the specific needs of the different user groups and develops separate information products tailored for particular target audiences. Transference occurs through the media of seminars, conferences, symposia, newsletters, and executive briefings. All publications are listed in the EPA ORD Publication Summary, EPA 600/2/76/013d, December 1976 and in the EPA Publications Bibliography Quarterly Abstract Bulletin, NTIS, Springfield, Virginia.

For further information concerning ongoing research write to:

Office of Research and Development, RD-683

U.S. Environmental Protection Agency

Washington, D.C. 20460

To obtain technical information publications, write to:

Environmental Research Information Center

U.S. Environmental Protection Agency

Cincinnati, Ohio 45268 


\section{NATIONAL AERONAUTICS AND SPACE ADMINISTRATION}

NASA, through its Office of Applications, supports oceanography related research efforts leading to the demonstration of applying aerospace technology and visible, infrared, and microwave remote sensing techniques to repetitive synoptic observations and measurements of ocean conditions and the quality of the marine environment on a global basis. To ensure that these activities are responsive to the needs or desires of other federal agencies for new or improved ocean data and information acquisition systems, the Office of Applications maintains a close cooperative working arrangement with those agencies during research planning, implementation, and assessment of accomplishments. To date, efforts have culminated in successful oceanography remote sensing experiments of NASA's series of Nimbus, Landsats-1, GEOS-3, Apollo, and Skylab orbital space flight missions. These experiments have demonstrated the utility of visible and infrared remote sensing techniques in providing information on circulation patterns, currents, sediment transport, pollutants, bioproductivity, sea ice conditions, and sea surface topography associated with sea mounts or deep ocean trenches. Emphasis is now being placed on the development and field testing of passive and active microwave remote sensors and a multispectral visible and near-infrared scanner to be used on Seasat-A and Nimbus-G respectively, which are to be launched during 1978. Seasat-T, the first in a series of Ocean Dynamics Satellites, will be placed in a nearly polar orbit to permit the acquisition of data relative to sea state, sea surface topography, wave directional spectra, sea surface wind speed and direction, ocean currents, ice cover, and geoidal variations every 36 hours. Investigations will be conducted to assess the utility of the Nimbus-G ocean color scanner for detecting, identifying, mapping, and quantifying ocean pollution, nutrient rich areas related to fisheries, coastal zone circulation patterns, and shoreline alterations.

For further information write to:

Deputy Associate Administrator for Applications

National Aeronautics and Space Administration

Washington, D.C. 20546 
NASA`s Scientific and Technical Information Facility. which is located adjacent to the Baltimore-Washington International Airport, collects the results of worldwide aerospace research and development. Major services include literature searches, bibliographies, distribution of documents, access to Department of Defense and Department of Energy data bases and to many additional scientific and technical data bases, and selective notification of new information and ongoing research.

\section{NATIONAL SCIENCE FOUNDATION}

The Division of Ocean Sciences of the National Science Foundation supports two research programs and a third program for acquisition and operation of research facilities.

Oceanography Project Support provides grants for developing fundamental knowledge about the oceans, primarily for studies in physical and biological oceanography, submarine geology and geophysics, and marine chemistry.

The International Decade of Ocean Exploration supports large-scale international investigations of the role of the ocean as related to climate, food production, pollution, energy, and natural resources. Four projects are incorporated in this program: (1) Environmental Forecasting, which is aimed at improved environmental prediction through better understanding of climate changes, the influence of the oceans on the atmosphere, and the part played by ocean circulation in shaping weather and climate; (2) Environmental Quality, which deals with the impact of man-made chemicals on the marine environment through study of the effects of pollutants on marine organisms, transfer of pollutants to the marine environment, and the worldwide distribution of geochemical features of ocean waters; (3) Seabed Assessment, which supports studies of the natural processes that result in formation and distribution of metal-rich manganese nodules, petroleum, and gas; and (4) Living Resources, which sponsors basic research in ocean processes that affect the development of living marine resources.

The Oceanographic Facilities and Support program provides major support for 30 research ships and several facilities operated by 15 academic oceanographic laboratories. The continuing objectives of this program are to maintain, improve, and effectively 
manage a cooperative system of oceanographic facilities at key locations in the academic community, and promote their shared use through the University National Oceanographic Laboratory System (UNOLS), an organization within that community.

Other divisions within the Foundation also sponsor projects relating to the marine environment, including research in ocean engineering, marine resource management, and the influence of the oceans on weather and climate.

For further information write to:

Office of the Assistant Director for Astronomical, Atmospheric, Earth, and Ocean Sciences

National Science Foundation

Washington, D.C. 20550

\section{SMITHSONIAN INSTITUTION}

The Smithsonian Institution's Museum of Natural History maintains the largest collection of biological specimens and geological samples in the world, an important resource for research on current and historical environmental conditions. An example of research projects carried out under the auspices of the Museum is Investigations of Marine Shallow Water Ecosystems, a study of the physical, chemical, and biological aspects of an undisturbed reef adjacent to Belize, British Honduras, which can be used as a baseline for comparison with polluted or otherwise disturbed reef systems.

Other activities in marine science include the following:

Scientific Event Alert Network, established in 1975 to serve as a clearinghouse for information on transient, biological, astronomical, and geological events.

Sinithsonian Oceanographic Sorting Center, which receives, sorts, records, and curates aquatic collections, makes specimens available to specialists, and maintains a data bank on the collections.

Chesapeake Bay Center for Environmental Studies, a long-term ecosystem study of the Rhode River estuary and watershed located on the western shore of Chesapeake Bay.

Smithsonian Tropical Research Institute, located in Panama, which is concerned with basic scientific questions of the evolutionary and ecological adaptations of tropical organisms. 
Fort Pierce Bureau, located at Link Port on the Indian River between Fort Pierce and Vero Beach, Florida, where studies include a baseline survey of the Indian River, life history investigations of marine animals, and development of rescue systems for small research submarines.

For further information write to:

Assistant to the Director

National Museum of Natural History

Smithsonian Institution

Washington, D.C. 20560

\section{ACCESS TO MARINE SCIENTIFIC AND TECHNICAL DATA AND INFORMATION}

\section{CURRENT RESEARCH INFORMATION}

Smithsonian Science Information Exchange, Inc.

The Smithsonian Science Information Exchange, Inc. (SSIE), a nonprofit corporation of the Smithsonian Institution located in Washington, D.C., was established in 1949 by six federal agencies engaged in the sponsorship and performance of research in the medical sciences. Over the years SSIE has expanded both the scope of its coverage and the extent of its services. Today the Exchange receives project information from over 1,300 organizations that sponsor research, including federal, state, and local government agencies; nonprofit associations and foundations; colleges and universities; and, to a limited extent, foreign research organizations and private industry. The active search file, which covers the two most recent fiscal years, now contains more than 200,000 descriptions of ongoing or recently terminated projects in all fields of science; nearly 6,000 of these are in marine science and engineering and closely related fields.

The basic record in the SSIE system is the singlepage Notice of Research Project (NRP), which contains the data elements essential to most users of the file: supporting organization name and control, grant, or contract number; performing organization name and address; investigator name(s); project title; period for the description; and a 200-word technical summary of the work to be performed. In some cases, funding information is also included. 
To meet a variety of user needs, the Exchange has developed a wide range of information products and services.

Custom Searches. In response to individual requests, staff scientists search the active file for NRP's on specific subjects. Searches for NRP's from particular performing organizations or departments, for geographic areas, or for any combination of similar requirements can also be made. The fee for this service is $\$ 60.00$ for the search and the first 50 NRP's sent, plus $\$ 0.25$ for each additional NRP. Estimates of coverage and costs for specific custom searches are available without charge.

Selective Dissemination of Information (SDI). The Exchange offers two types of SDI service for users who wish to receive regular updates of custom searches or research information packages (see below). SSIE scientists establish a user interest profile for each SDI subscriber; then periodic searches of the active file are conducted against this search profile to identify all new or newly updated project notices added to the data base since a previous search was made.

Subscribers to Standard SDI Service receive 12 monthly search updates, compiled automatically by computer, for a single fee of $\$ 180.00$. Custom SDI Service provides subscribers with quarterly updates, each of which is carefully reviewed by a staff scientist to assure maximum relevance of update contents to search profile requirements. The quarterly cost of Custom SDI Service is $\$ 50.00$ for the search service and the first 1 to 50 NRP's, plus $\$ 0.25$ for each additional NRP.

Investigator or Accession Number Searches. Searches of the active file can be performed by principal or coinvestigator name ( $\$ 2.00$ per name), or by SSIE accession or agency control number $(\$ 1.00$ per number). Minimum order: $\$ 10.00$.

SDC/SSIE On-Line Search Service. The SSIE data base is available on-line for users with access to a computer terminal who wish to search the file directly. Further information about this service can be obtained from System Development Corporation (SDC) at 2500 Colorado Avenue, Santa Monica, California 90406, or 7929 Westpark Drive, McLean, Virginia 22101.

Aids developed by SDC and SSIE to assist on-line users in conducting searches through the SDC system include manuals describing SDC's retrieval program applications, a guide to the SSIE subject indexing system, and a three-volume computer printout of over 90,000 
SSIE Subject Terms and Synonyms. This printout has proven useful not only in querying the SSIE file, but also in designing subject search strategies for other data bases.

Research Information Packages. SSIE scientists regularly conduct and review searches of the active file for NRP's on topics of high current interest. The results of these searches are compiled into research information packages which, once established, are available at costs that represent significant savings over those for custom searches. Package contents are updated every 90 days.

Prices vary according to the average annual number of NRP's expected to be included. Because the contents of the data base fluctuate, packages compiled at different times during the year may contain NRP counts outside the range indicated by their published price.

Packages priced at $\$ 35$ contain up to 25 NRP's; those at \$45, 26-100 NRP's; at \$55, 101-200 NRP's; and so on.

Research information packages now available in marine science and engineering include the following:

\section{Oceanography}

LO01L Oceanographic acoustics and applications: Acoustical characteristics of seawater and marine sediments, sonar and sofar, bioacoustics $\$ 65$

LO02L Use of buoys for oceanographic data collection $\$ 55$

LO03L Bathymetric mapping \$45

LO04L Igneous and metamorphic rocks on the seafloor $\$ 45$

LO05L Coastal zone management \$55

LO06L Seismic profile systems in oceanography $\$ 45$

LO08L Ocean drilling and core analysis \$55

LO10L Metals and trace elements in seawater and marine sediments $\$ 45$

LO12L Sea ice \$45

LO15L Ocean sediment types \$45

LO16L Ocean sediment properties $\$ 55$

LO17L Ocean topography \$55

LO18L Ocean turbidity and turbidity currents \$45

LO19L Ocean thermal properties \$55

LO20L Use of bathythermographs \$35

LO21L Continental shelves and slopes, continental margins $\$ 55$

LO22L Oceanographic magnetics \$45

LO23L Remote sensing of the ocean surface: Detection and identification of water pollutants, 
water temperature, heat flow, sea-air interaction, ocean current dynamics $\$ 55$

LO24L Oceanographic gravity $\$ 45$

LB13L Energy derivation from the ocean's thermal structure $\$ 45$

LM09L Ocean mining \$55

(NOTE: Contains material in LM25L.)

LM25L Offshore oil and gas \$45

LT09L Sand dunes \$35

LT16L Coastal erosion \$45

AW17L Drugs from the sea $\$ 45$

CA05L Social impacts and public involvement in marine environment development $\$ 45$

FQ02L Underwater photography \$35

GT11L Use of submersibles for underwater research $\$ 35$

IB32L Wind power, tidal and sea wave power, power from ocean currents and gradients $\$ 55$

(NOTE: Contains material in LB13L.)

IQ02L Underwater acoustics: Transmission and attenuation characteristics of fresh- and seawater, underwater imaging and detection \$35

IZ03L Underwater optics: Transmission, scattering, and optical properties of fresh- and sea-water; underwater surveillance; optical source development $\$ 45$

JJ05L Marine and underwater communication systems (excludes sonar) $\$ 45$

\section{KC53L Computer usage in oceanography \$45}

Marine and Naval Engineering and Operations

GA94L Ship and marine noise and vibrations $\$ 45$

GJ01L Coastal engineering: Breakwaters, ports, harbors, piles, and other coastal structures $\$ 55$

GJ05L Dikes and levees \$45

GJ06L Offshore structures: Bottom-supported and floating platforms $\$ 45$

GK05L Submarine soil mechanics \$45

GK14L Deep foundations: Caissons, piers, and pile foundations $\$ 45$

GT02L Ship hulls, submarine hulls, hull foams, and hull-like structures $\$ 45$

GT03L Marine anchors and mooring systems \$45

GT06L Marine and ship propellers \$45

GT07L Ship models and simulators \$45

GT08L Submarines: Design, construction, hydrodynamics, structural components, dynamic responses, stability and control $\$ 55$

(NOTE: Contains material in GT11L.) 
GT09L Ship motion and stabilities: Gyration, roll, dynamic responses, performance, maneuverability $\$ 55$

GT11L Use of submersibles for underwater research $\$ 35$

GU01L Antisubmarine warfare $\$ 55$

GU11L Torpedoes \$45

GU12L Naval logistics \$45

GV05L Underwater construction \$35

HM03L Marine corrosion and fouling \$45

HT11L Wood preservation \$45

JJ05L Marine and underwater communication systems (excludes sonar) $\$ 45$

JQ02L Navigational and landing aids: Autopilots, beacons, direction finders, compasses $\$ 45$

JQ05L Sonar and echo sounding systems \$55

JQ07L Satellite and space navigation systems \$35

JQ08L Radio navigation systems \$35

JQ09L Marine, ship, and underwater navigation systems $\$ 35$

JQ10L Position location systems \$45

LT11L Scouring in streams, estuaries, and coastal zones $\$ 45$

LT16L Coastal erosion \$45

\section{Meteorology}

LR03L Tropical cyclones: Hurricanes and typhoons $\$ 45$

LR14L Atmospheric radiation balance and heat exchange $\$ 55$

LR18L Weather sensing by rockets and satellites $\$ 55$

LR19L Wind velocity \$45

\section{Environmental Quality}

BA29L Bioenvironmental effects of electric power plants $\$ 75$

(NOTE: Contains material in BA52L.)

BA42L Microbial degradation of petroleum and other hydrocarbons $\$ 45$

BA51L Pollution of coral reefs \$35

CA05L Social impacts and public involvement in marine environment development $\$ 45$

FA05L Oil pollution cleanup: Analysis, separation, and removal of oil from sources such as oil spills and industrial wastes $\$ 45$

(NOTE: Contains material in BA42L.)

FA14L Lead as a pollutant: Analysis and removal of lead from air, water, or wastes; sources of the pollutant $\$ 55$ 
FA35L Sewage sludge disposal methods: Burial, incineration, landfills, ocean dumping $\$ 55$

GA47L Dredging and dredged materials \$45

IV13L Nuclear waste management \$55

LA30L Marine disposal and dumping of sewage, ship wastes, industrial and other solid wastes $\$ 45$

LA38L Natural disasters: Floods, earthquakes, avalanches, landslides, tsunamis, volcanic eruptions $\$ 85$

LA75L Environmental baseline measurements for power plant siting $\$ 55$

LA76L Environmental standards and impact statements for power plants $\$ 45$

LA79L Impact of electric power plants on the environment $\$ 75$

(NOTE: Contains material in BA29L, BA33L, BA52L, LA16L, LA76L.)

\section{Water Quality}

LA04L Eutrophication of lakes, streams, reservoirs, and coastal waters; eutrophication control $\$ 65$

LA13L Turbidity in oceans, bays, streams, and lakes $\$ 55$

LA15L Effects of dredging on freshwater and marine environments $\$ 45$

LA16L Thermal water pollution: Heated water discharges from power plants into natural waters \$65

(NOTE: Contains material in BA33L.)

LA30L Marine disposal and dumping of sewage, ship wastes, industrial and other solid wastes $\$ 45$

LA31L Water pollution in estuarine and coastal zones: Identification, effects, and control of pollutants $\$ 95$

LA32L Oil pollution in the marine environment: Detection, effects, treatment $\$ 65$

LA37L Oil spill monitoring \$35

LA44L Monitoring and analysis of marine pollution $\$ 45$

LA72L Carriage and transport of pollutants by elements of the hydrologic cycle $\$ 95$

LA82L Water quality in harbors and ports $\$ 45$

BA05L Shellfish as bioindicators of pollution $\$ 35$

BA06L Toxic and ecologic effects of petroleum and crude oil on animals, plants, and humans; biodegradation of petroleum pollutants and toxicity of petroleum $\$ 55$ (NOTE: Contains material in BA42L, LA32L.) 
BA19L Algal population growth and eutrophication of marine and freshwater systems $\$ 55$

(NOTE: Contains material in BA40L.)

BA21L Diatoms and other algae as indicators of water quality $\$ 45$

BA33L Ecological effects of thermal pollution: Mixing and dispersion of thermally enriched waters, waste heat utilization $\$ 55$

BA35L Tidal marshes: Ecological surveys, management, and pollution effects for marine, estuarine, and salt marshes $\$ 45$

BA37L Bacterial pollution of water $\$ 55$

BA39L Management of coastal and estuarine development with respect to water quality $\$ 45$

BA42L Microbial degradation of petroleum and other hydrocarbons $\$ 45$

BQ11L Effects of fisheries and seafood processing on water quality $\$ 45$

FA07L Wastes from food processing: Treatment, disposal, and reclamation of food processing wastes by chemical, physical, and biological methods $\$ 55$

FA12L Determination of organic substances in natural water: Detection and analysis of pesticides, oil, hydrocarbons $\$ 55$

FA13L Mercury as a water pollutant: Analytical techniques for the detection of mercury levels in fish and water, physiological effects on fish, potential as a human health hazard $\$ 55$

FA16L Petroleum refinery and petrochemical industrial wastewater treatment and disposal $\$ 45$

FA28L Viruses in water: Detection, monitoring, and removal $\$ 45$

\section{Environment and Ecology}

BA01L Chlorophyceae and Charophyceae (green algae) $\$ 55$

BA02L Diatoms \$45

BA04L Marine fouling organisms \$45

BA05L Shellfish as bioindicators of pollution \$35

BA06L Toxic and ecologic effects of petroleum and crude oil on animals, plants, and humans; biodegradation of petroleum pollutants and toxicity of petroleum dispersant chemicals \$55 (NOTE: Contains material in BA42L, LA32L.)

BA07L Aquatic species diversity measurements \$45

BA08L Starfish \$35

BA10L Cetacea $\$ 45$ 
BA11L Computer modeling of marine biological populations $\$ 45$

\section{BA12L Bacterial slime $\$ 45$}

BA17L Biological effects of zinc or boron pollution $\$ 45$

BA19L Algal population growth and eutrophication of marine and freshwater systems $\$ 55$

(NOTE: Contains material in BA40L.)

BA20L Effects of light quantity and quality on aquatic algae $\$ 45$

BA21L Diatoms and other algae as indicators of water quality $\$ 45$

BA22L Cyanophyta (blue-green algae) $\$ 55$

BA23L Euglenophyta $\$ 45$

BA24L Kelps \$35

BA25L Dinoflagellates $\$ 45$

BA28L Red Tides $\$ 35$

BA29L Bioenvironmental effects of electric power plants $\$ 75$

(NOTE: Contains material in BA52L.)

BA33L Ecological effects of thermal pollution: Mixing and dispersion of thermally enriched waters, waste heat utilization $\$ 55$

BA35L Tidal marshes: Ecological surveys, management, and pollution effects for marine, estuarine, and salt marshes $\$ 45$

BA37L Bacterial pollution of water $\$ 55$

BA39L Management of coastal and estuarine development with respect to water quality $\$ 45$

BA40L Primary productivity of phytoplankton $\$ 45$

BA42L Microbial degradation of petroleum and other hydrocarbons $\$ 45$

BA45L Marine food chains and environmental relationships $\$ 45$

BA46L Vertical distribution of marine plankton in relationship to acoustic properties of water $\$ 35$

BA50L Detection of enteric viruses in the environment $\$ 35$

BA51L Pollution of coral reefs $\$ 35$

BA52L Impingement, entrainment, or entrapment of aquatic organisms by water intake structures of power plants $\$ 35$

BJ18L Sea urchins $\$ 45$

BJ38L Biotransformation of mercury by microorganisms in aquatic sediments: Methylation, effects, mercury cycling in aquatic environments $\$ 45$ 


\section{Fish and Wildlife}

BA05L Shellfish as bioindications of pollution $\$ 35$

BA06L Toxic and ecologic effects of petroleum and crude oil on animals, plants, and humans; biodegradation of petroleum pollutants and toxicity of petroleum dispersant chemicals $\$ 55$ (NOTE: Contains material in BA42L, LA32L.)

BA08L Starfish \$35

BA10L Cetacea $\$ 45$

BA11L Computer modeling of marine biological populations $\$ 45$

BA35L Tidal marshes: Ecological surveys, management, and pollution effects for marine, estuarine, and salt marshes $\$ 45$

BA37L Bacterial pollution of water $\$ 55$

BA45L Marine food chains and environmental relationships $\$ 45$

BP20L Thermal tolerance and acclimatization in fish $\$ 35$

BP21L Osmoregulation in aquatic vertebrates $\$ 45$

BQ03L Coho salmon \$45

BQ06L Economics of aquaculture \$45

BQ07L Shellfish pathology $\$ 45$

BQ08L Fish spawning sites: Nursery areas, artificial beds, rehabilitation of suitable natural areas, physical properties of sites $\$ 55$

BQ11L Effects of fisheries and seafood processing on water quality $\$ 45$

BQ15L Legislative, administrative, and sociocultural influences on the management of marine commercial fisheries $\$ 45$

BQ17L Marine and estuarine aquaculture \$45 (NOTE: Contains material in BQ26L.)

BQ1 8L Sonic tagging of fish \$35

BQ26L Role of algae in aquaculture \$35

BQ27L Marine mammals \$55 (NOTE: Contains material in BA10L.)

EQ05L Control of undesired fish by chemical, biological, cultural, or physical means $\$ 45$

EQ12L Waterfowl censusing \$35

EQ15L Creel censusing of fish $\$ 45$

EQ16L Nesting sites of waterfowl including use of artificial nests $\$ 35$

\section{Recreation}

AA06L Effects of water pollution on utilization of outdoor recreation sites by the public $\$ 45$ 
AO18L Diving physiology and pathology $\$ 55$

(NOTE: Contains material in AO23L.)

AO23L Physiological and pathological aspects of hyperbaric oxygen $\$ 45$

ER03L Commercial sport fishing or hunting of game birds or large game animals $\$ 45$

ER04L Relationship between water quality and recreational use $\$ 55$

ER10L Water-based recreation, including fishing \$55 (NOTE: Contains material in ER18L.)

ER18L Water sports: Swimming, boating, water skiing, and scuba diving $\$ 45$

For further information write to:

Smithsonian Science

Information Exchange, Inc.

Room 300, 1730 M Street, N.W.

Washington, D.C. 20036

\section{ENVIRONMENTAL DATA AND INFORMATION}

\section{National Technical Information Service (NTIS)}

The National Technical Information Service is the central source for the public sale of government-sponsored research, development, and engineering reports and other analyses prepared by federal agencies, their contractors or grantees, or by special technology groups. It is also a central source for federally generated machineprocessable data files. The information collection exceeds 1 million titles and all are available for sale. About 105,000 titles are stocked in multiple copies. Current lists of best selling reports describe those most in demand.

NTIS announces some 1,500 new reports each year on marine engineering, including harbors, port facilities and marine navigation; dynamic oceanography; physical and chemical oceanography; biological oceanography; marine geophysics and geology; oceanographic vessels, instruments; platforms and underwater research vehicles; hydrography; and underwater construction and habitats.

Customers can quickly locate summaries of interests from among 480,000 federally sponsored research reports completed and published from 1964 to date by using the agency's on-line computer search service, NTI Search, or by referring to more than 1,000 Published Searches. About 60,000 new summaries and reports are 
added annually. Copies of the whole research reports on which the summaries are based are sold by NTIS in paper or microform.

The NTIS Bibliographic Data File, on magnetic tape, includes unpublished research summaries and is available for lease. The computer products of other federal agencies are sold or leased by NTIS.

Current summaries of new research reports and other specialized information in various categories of interest are published in some 26 weekly, indexed newsletters, including one entitled Ocean Technology. An all-inclusive biweekly journal, Government Reports Announcements \& Index, is published for librarians, technical information specialists, and those requiring all the summaries in a single volume.

A standing order microfiche service (SRIM) automatically provides subscribers with the full texts of research reports especially selected to satisfy individual requirements. Automatic distribution of paperbound reports is also available.

The above and additional information products and services are described in the free NTIS general catalog (PR-154).

For further information write to:

National Technical Information Service

U.S. Department of Commerce

Information Center \& Bookstore

425 - 13th Street, N.W.

Washington, D.C. 20004

Oceanic and Atmospheric Scientific Information System (OASIS)

The Environmental Science Information Center of NOAA's Environmental Data and Information Service offers automated literature searches through the Oceanic and Atmospheric Scientific Information System (OASIS) to both NOAA and non-NOAA users. OASIS allows computerized access to some 11 million references to published scientific and technicial information: The more than 40 data bases that make up OASIS can be searched for any subject in the atmospheric, marine, and earth sciences. Among data bases pertinent to marine science and technology are Aquaculture, Bibliography and Index of Geology, Engineering Index Compendex, The Fish and Wildlife Reference Service, Meteorological and Geoastrophysical Abstracts, Oceanic Abstracts, Petroleum Abstracts, Pollution, Selected Water Resources Abstracts, Enviroline, Aquatic Sci- 
ences and Fisheries Abstracts, Biological Abstracts, and Petroleum Abstracts.

For further information write to:

Users Services Branch

Library and Information Services Division

Environmental Science Information Center

Environmental Data and Information Service

National Oceanic and Atmospheric Administration

Rockville, Maryland 20852

\section{Environmental Data Index (ENDEX)}

Developed by NOAA's Environmental Data and Information Service, the Environmental Data Index (ENDEX) contains computer-searchable descriptions of interdisciplinary files of environmental data on many levels. ENDEX has three major components: (1) descriptions of data collection efforts, (2) descriptions of data files, and (3) detailed inventories of large, commonly used files. The data file description lists the types of parameters and volumes of data available; methods of measurements; when and where the data were collected; sensors and platforms used; data formats; restrictions on data availability; publications in which the data can be found; whom to contact for further information; and estimated cost of obtaining the data.

ENDEX services and products include the following: (1) access to specialized indexes of environmental data, grouped by geographic areas, institutions, or disciplines; (2) on-line, interactive searches of indexes to answer specific questions concerning the availability and whereabouts of data files; (3) quick-response determination of the costs of retrieval from large data files; and (4) data catalogs from large NOAA environmental data collection projects. Individual ENDEX data files descriptions are updated every 2 years.

For further information write to:

Data Index Branch

National Oceanographic Data Center

Environmental Data and Information Service

National Oceanic and Atmospheric Administration

Washington, D.C. 20235

\section{Regional Coastal Information Centers (RCIC)}

The Regional Coastal Information Center (RCIC) concept is a new approach to making coastal and marine 
information and data locally available to those who need it. There is a growing constituency for such services, particularly as more and more of the management of coastal resources is being undertaken by state and local governments.

The RCIC program is sponsored jointly by three NOAA components: the Marine Advisory Service, Environmental Data and Information Service, and Office of Coastal Zone Management.

Working on a regional basis, the RCIC can identify resources that relate to the coastal and marine environment of the region, whether resources are academic. private, industrial, or governmental, and whether held locally, regionally, or nationally. Users are able to request materials or referral to resources within the region and throughout the country.

At present, three RCICs are operational: the Northeast RCIC located at the University of Rhode Island in Narragansett; the Northwest RCIC located jointly at the University of Washington in Seattle and Oregon State University in Corvallis; and the Great Lakes RCIC located jointly at the University of Michigan and Great Lakes Basin Commission in Ann Arbor. Eventually there will be nine RCICs, covering all U.S. coastal zone regions. including Alaska and Hawaii.

For further information write to:

Mr. Robert Shephard

Office of Sea Grant

National Oceanic and Atmospheric Administration

Washington, D.C. 20235

\section{EDIS Data Centers}

The Environmental Data and Information Service (EDIS), NOAA, was specifically created to manage environmental data. Of the six EDIS centers, three maintain collections and provide services related to marine science and technology.

The National Oceanographic Data Center (NODC) disseminates oceanographic data, develops analytical and descriptive products to meet user requirements, and provides facilities for the World Data Center-A (Oceanography). Oceanographic data available from NODC include: mechanical and expendable bathythermograph data in analog and digital form; oceanographic station data for surface and serial depths, giving values of temperature, salinity, oxygen, inorganic phosphate, total phosphorus, nitrite-nitrogen, silicate-silicon, and $\mathrm{pH}$; 
continuously recorded salinity-temperature-depth data in digital form; surface current information obtained with drift bottles or calculated from ship set or drift; and biological data, giving values of plankton standing crop, chlorophyll concentrations, and rates of primary productivity.

For further information write to:

\section{National Oceanographic Data Center}

Environmental Data and Information Service

National Oceanic and Atmospheric Administration

Washington, D.C. 20235

The National Climatic Center (NCC) in addition to being the custodian of all United States weather records, is also the repository for data collected during largescale investigations of the air-sea interface. Such special collections include data from the International Field Year for the Great Lakes (IFYGL), a 1972-73 field study of the physical, chemical, and biological processes of Lake Ontario; from the Barbados Oceanographic and Meteorological Experiment (BOMEX), conducted in 1969; and from the GARP (Global Atmospheric Research Program) Atlantic Tropical Experiment (GATE), a multinational experiment conducted in the eastern Atlantic in the summer of 1974.

For further information write to:

National Climatic Center

Environmental Data and Information Service

National Oceanic and Atmospheric Administration

Federal Building

Asheville, North Carolina 28801

Environmental and earth resources satellite data, including both visible light imagery and infrared data are available from NCC's Satellite Data Services Branch.

For further information write to:

Satellite Data Services Branch

World Weather Building, Room 606

Washington, D.C. 20233

The National Geophysical and Solar-Terrestrial Data Center (NGSDC) disseminates solid earth and marine geophysical data, including bathymetric measurements; seismic profiles; gravimetric measurements; geomagnetic total field measurements, and geological data on heat flows, cores, samples, and sediments. 
For further information write to:

National Geophysical and

Solar-Terrestrial Data Center

National Oceanic and Atmospheric Administration

Boulder, Colorado 80302

\section{NON-GOVERNMENT SOURCES OF INFORMATION}

The Information Industry Association (IIA) is made up of over 100 companies offering information products, services, and systems in specific subjects. More than 150 data bases are available. Information companies serve a particular market function or subject area, such as manufacturing data bases, distributing information, performing specialized searches, and providing information for problem-solving. For a description on subject specialties in the membership directory, Information Sources, write to:

Information Industry Association

4720 Montgomery Lane

Bethesda, Maryland 20014

Lockheed Information Services operates DIALOG, an online information system. Over 70 data bases include bibliographies, conference proceedings, descriptions of current research, directories, periodicals, and reports in all major disciplines. Among the data bases listed are Aquatic Sciences and Fisheries Abstracts, Oceanic Abstracts, and Pollution Abstracts. The Selective Dissemination of Information (SDI) searches are being expanded.

For information write to:

Lockheed Information Systems

DIALOG Marketing, Dept. 50-20/201

3251 Hanover Street

Palo Alto, California 94304

The Raytheon Service Company (RSC), a wholly owned subsidiary of the Raytheon Company, operates clearing houses, information retrieval systems, and related information-management services on engineering and technical services worldwide. It provides printing services, audio-visual materials, and technical studies. Technical Information Services handle complete library 
services, including translations and abstracts in 13 languages.

For information write to:

Raytheon Service Company

Spencer Laboratory

2 Wayside Road

P.O. Box 503

Burlington, Massachusetts 01803

The Departments of Energy and Industry of the United Kingdom are supporting the Marine Information and Advisory Service (MIAS), which incorporates the former British Oceanographic Data Service, at the Institute of Oceanographic Science (IOS). MIAS is to assist government and industry with requests for oceanographic data. The "Marine Information and Advisory Service Leaflet" and the "MIAS Introductory User Guide," both produced by the IOS, describe the variety of products to be available from the computerized data bank.

For more information write to:

MIAS Enquiry Desk

Institute of Oceanographic Services

Brook Road

Wormley, Godalming, Surrey

HU8 5UB ENGLAND 


\section{SUBJECT TERMS FOR ACCESS TO FEDERAL MARINE SCIENCE AND ENGINEERING PROJECT INFORMATION Compiled by SSIE}

Abyssal Environment Acoustical Properties Activated Carbon Adaptive Radiation Adriatic Sea Adsorption Capacity Advection

Aeration

Aerobic Bacteria Aeromagnetics Aerosols Aftershocks Agricultural Wastes Agulhas Current Air - Sea Boundary Studies

Heat and Radiation Transfer

Particle - Gas Transfer

Wind - Water Interaction

Air Census

Air Motion

Advection

Air Patterns and

Circulation

Air Turbulence

Convection

Gravity Waves

Wind

Ocean - Lake Winds

Orographic Effects

Wind Direction

Wind Profiles

Wind Shear

Wind Velocity

Air Pollution

Monitoring

Air Pollution Sources

Air Pollution Types

Air Pressure - Density

Air Temperature

Airboats

Aircraft

Alaska

Albemarle Sound

Aleutian Islands

Algae

Algae - Chlorophyta

Algae - Chrysophyta

Diatoms - general

Algae - Cyanophyta

Algae - Euglenophyta
Algae - Phaeophyta

Algae - Pyrrophyta

Algal Toxins

Aluminum

American Samoa

Amino Acids

Ammonia

Ammonium

Amoeba

Amphibians

Amphibious Operations

Amphipods

Anaerobic Bacteria

Analysis of Variance

Anchoring and Mooring Systems

Anchovies

Andesite

Animal Migration

Animal Toxins

Annelida

Oligochaeta

Polychaeta

Anorthosite

Antarctic Ocean

Ross Sea

Scotia Sea

Weddell Sea

Antarctica

Anthozoa

Antilles

Antimony

Antisubmarine Warfare

Aquaculture

Fish Farming

Plant Aquaculture

Shellfish Farming

Aquaria

Arachnida

Arctic

Arctic Ocean

Baffin Bay

Barents Sea

Beaufort Sea

Chukchi Sea

East Siberian Sea

Greenland Sea

Hudson Bay

Laptev Sea

Lincoln Sea

Argon - Potassium Dating

Arsenic

Arthropods

Artificial Islands 


\begin{tabular}{|c|c|}
\hline Aschelminthes & Basalt \\
\hline Nematoda & Basic - Mafic Rocks \\
\hline Asteroids & Basins -sedimentary- \\
\hline Atlantic Coastal Plain & structural \\
\hline Atlantic Ocean -general & Bathyal Environment \\
\hline Atlantic Ocean -north & Bathymetry \\
\hline Atlantic Ocean -south & Bathythermographs \\
\hline Atmosphere Disturbance & Bauxite \\
\hline Cyclones - Anticyclones & Bay of Biscay \\
\hline Fronts & Bayous \\
\hline Monsoons & Bay - Bights \\
\hline Severe Storms - Squalls & Beaches \\
\hline Thunderstorms & Beaufort Sea \\
\hline Tornadoes - Waterspouts & Bed Load \\
\hline Tropical Cyclones - & Bedding Planes \\
\hline Hurricanes & Beds Under Water \\
\hline Atmosphere Electricity & Behavior - invertebrate \\
\hline Atmosphere Energy - & Benefit-cost Analysis \\
\hline Radiation & Benthic Fauna \\
\hline Air Temperature & Benthic Flora \\
\hline Heat Balance - Budget & Benthonic Environment \\
\hline Heat Exchange & Bering Sea \\
\hline Atmosphere History & Bermuda \\
\hline Atmospheric Pollution & Beryllium \\
\hline Air Pollution Monitoring & Billfishes \\
\hline Air Pollution Sources & Bioassays \\
\hline Air Pollution Types & Biochemical Evolution \\
\hline Aerosols & Biogenous Sediments \\
\hline Gases & Bioindicators \\
\hline Particulates & Biological Oxygen Demand \\
\hline Radioactivity & Biological Rhythms \\
\hline Dispersion - & Spawning \\
\hline Transportation & Bioluminescence \\
\hline Atolls & invertebrate \\
\hline Atomic Plants & Biostratigraphy - \\
\hline Australia & Biofacies \\
\hline Azores and Madeira & $\begin{array}{l}\text { Biotelemetry } \\
\text { Birds }\end{array}$ \\
\hline Islands & $\begin{array}{l}\text { Birds } \\
\text { Ducks, Geese, and Swans }\end{array}$ \\
\hline B O M E X & Gulls, Plovers, Etc. \\
\hline Bacteria & Pelicans, Cormorants, Etc. \\
\hline Aerobic Bacteria & Bituminous Shale \\
\hline Anaerobic Bacteria & Black Sea \\
\hline Coliforms -nonspecific & Bluefishes \\
\hline Escherichia Coli & Boat Discharges \\
\hline Heterotrophic Bacteria & $\begin{array}{l}\text { Boating } \\
\text { Boats and Hydrofoil }\end{array}$ \\
\hline $\begin{array}{l}\text { Marine Bacteria } \\
\text { Pseudomonas - nonspecific }\end{array}$ & $\begin{array}{l}\text { Boats and Hydrofoil } \\
\text { Crafts }\end{array}$ \\
\hline $\begin{array}{l}\text { Pseudomonas - nonspecific } \\
\text { Bacterial Endotoxins }\end{array}$ & Bonin Islands \\
\hline Bacterial Exotoxins & Borehole Geophysics \\
\hline Bacteriophage & Brachiopods \\
\hline Baffin Bay & Breakwaters \\
\hline Bait Fish Rearing & Breccia -general \\
\hline Balloons & British West Indies \\
\hline Baltic Sea & Bryozoans \\
\hline Barents Sea & Buoys \\
\hline Barges & \\
\hline Barium & Cadmium \\
\hline Barnacles & Calcification \\
\hline Bars & Calcium \\
\hline
\end{tabular}


California

California Current

Canals

Canary Islands

Cancer

Cancer Chemotherapy

Cape Verde Islands

Capes - Peninsulas

Carbon

Carbon Dioxide

Carbon Isotopes

Carbonates

Carbon 14 Dating

Carbonates

Cargo and Passenger

Ships

Caribbean Sea

Carnivors

Caroline Islands

Cartilaginous Fishes

Catalogs, Tables,

Compilations

Cephalopods

Cesium

Cetacea

Channels

Charts

Chemical Analysis

Chemical Oxidation

Chemical Reactions

Chemical Sediments

Chert

Chesapeake Bay

Chlorination

Chlorine

Chlorophyll

Chromium

Chukchi Sea

Ciliata

Cinder Cones

Cirrus Clouds

Clams

Clay Minerals

Clay Soils

Claystone

Clouds

Cirrus Clouds

Cloud Cover

Cloud Formation and Evolution

Cloud Motions Movement

Cloud Patterns

Cloud Physics

Cloud Structure

Cumulus Clouds

Clouds - Precipitation

Cnidosporidia

Coal

Coastal Engineering
Coastal Plain

Atlantic Coastal Plain

Gulf Coastal Plain

Coastlines - Shorelines

Cobalt

Coccoliths

Codfishes and Hakes

Coelenterata

Anthozoa

Hydrozoa

Scyphozoa

Coliforms -nonspecific

Columbia River

Comb Jellies

Combined Sewers

Commodities

Comparative AnatomyEvolution

Comparative Physiology

Compressional Waves

Computer Models

Condensation Physics

Conglomerates

Connecticut River

Conodonts

Continent History

Continental Drift

Continental Shelf

Continental Slope

Continents

Convection

Convection Currents

Copepods

Copper

Coral Sea

Corals

Core

Core Analysis

Correlation

Corrosion, Deterioration

Corrosion Agents

Corrosion Effects

Fouling

Stress Corrosion

Thermal Degradation

Corrosion Prevention

Corrosion Rates

Cosmogenous Sediments

Costs

Crabs

Cratons - Platforms

Crayfish

Creel Census

Creosote

Crinoids

Cruises

Crust

Crustacea

Barnacles

Copepods 
Eucarids

Crabs

Crayfish

Lobsters

Prawns

Shrimps

Ostracods

Peracarids

Amphipods

Isopods

Crustal Movement

Detectors

Crystal Chemistry

Crystallization

Cuba

Cumulus Clouds

Currents -bottom

Currents -longshore littoral

Cyclones - Anticyclones

Cyprus

Cytotoxic Agents

\section{DDE}

DDT

Decompression Sickness

Deep Sea Drilling J O I D E S

Deep Submersibles

Deformation

Degradation

Delaware Bay

Delaware River

Deltas

Demand for Recreation

Denitrification

Density, Sea Water

Depth -water

Depth, Sea Water

Desoxyribonucleic Acid

Developmental Physiology

Dew

Dewatering

Diabase

Diatoms -general

Dicotyledons

Dieldrin

Digestion

Dikes

Dinoflagellates

Discharge

Discontinuities

Disinfection

Dispersion - Transportation

Dissolved Load

Divers

Diving and Scuba Gear

Dolomite

Domestic Wastes

Sanitary Landfills

Sewage
Dredging

Drift Stations

Drilling and Coring

Drugs

Drums

Ducks, Geese, and Swans

Dyes

Earth Electrical Properties

Earth Telluric Current

Exploration Methods

Electric Logging

Electromagnetic Probing

Earth Interior

Earth Magnetism

Exploration Methods

Aeromagnetics

Magnetic Surveys

Magnetic Anomalies

Magnetic Field Character Field Reversals

Magnetic Intensity

Paleomagnetism

Polar Wandering

Rock and Mineral Magnetics

Secular Magnetic Variation

Earth Thermal Properties

Convection Currents

Geothermal Gradient

Heat Flows

Earth Tides

Earthquake Location

Earthquakes

East China Sea

East Siberian Sea

Easter Island

Echinoderms

Asteroids

Crinoids

Echinoids

Holothuroids

Ecological Effects

Ecological Evolution

Economic Mineral

Appraisals

Dimensions - Distribution

Potential of Deposit

Resource Inventories

Economics

Benefit-cost Analysis

Commodities

Fish and Shellfish

Economic Impact

Income Analysis

International Economics

International Trade

Microeconomics

Costs

Market Structure

Marketing

Production and Processing 
Natural Resources

Economics

Land Economics

Optimization

Regional Economics

Regional Base Studies

Regional Impact

Economics -recreation

Effluent Standards

Effluents - Waste Water

Elastic Waves

Electric Logging

Electric Power Plants

Electrical Properties

Electro-fishing

Electromagnetic Properties

Electronics

Image Sensing Systems

Night Vision Detection Systems

Remote Sensing Systems

Element Ratios

EM Radiation

Emergent Shorelines

Energy - Environmental Aspects

English Channel

Entomology

Environmental Effects

Environmental Hazards

Environments, Human

Pressure

Decompression Sickness

Nitrogen and Inert

Gas Narcosis

Temperature and Humidity Cold

Enzyme Studies

Eocene Epoch

Epeirogenic Movement isostasy

Equatorial Currents

Erosion

Escherichia Coli

Estuaries

Ethological Evolution

Eucarids

Eutrophication

Evaporation

Evaporites

Evolution, Organic

Biochemical Evolution

Comparative AnatomyEvolution

Comparative Physiology

Ecological Evolution

Ethological Evolution

Genetic Evolution

Geologic Evolution

Speciation
Evolutionary Studies

Exchange Capacity

Experimental Geochemistry

Exploration Methods

Explosives

Extinction

Extrusive Igneous Rocks

Fats - Lipids and Oils

Ferry Boats

Field Reversals

Fiji Islands

Filtration

Fine-grained Clastics

Fish

Anchovies

Billfishes

Bluefishes

Cartilaginous Fishes

Ratfishes

Sawfishes

Sharks

Codfishes, Hakes

Drums

Freshwater Catfishes

Herring, Shad, Menhaden

Jacks, Scads, Pompanos

Killifishes

Lampreys, Hagfishes

Lefteye Flounders

Mackerels, Tunas

Minnows, Carps

Mullets

Perches

Porgies

Righteye Flounders

Scorpionfishes, Rockfishes

Sea Basses

Smelts

Surfperches

Trout, Whitefish, Graylings

Salmon

Trout

Whitefish, Cisco

Fish and Shellfish

Fish Capture

Drugs

Electro-fishing

Nets

Tags

Telemetry

Fish Censusing

Air Census

Creel Census

Questionnaires

Fish Farming

Fish Protein Concentrate

Fish Spawning and

Nesting 
Fishing

Fishing Gear

Fission Reactors

Fission Track Dating

Fissure Eruptions

Fjords

Flagellata

Floods

Florida

Florida Current

Flysch Deposits

Fog - Haze - Mist

Fog - Mist Dissipation

Food Chains

Food Fish and Shellfish Clams

Crabs

Fish -nonspecific

Fish Protein

Concentrate

Hake

Lobster

Oysters

Salmon

Scallops

Shrimp

Trout

Tuna

Food Processing

Food Webs

Foraminifera

Formosa - Taiwan

Fossil Age Studies

Fossil Dating

Fossil Invertebrates

Arthropods

Ostracods

Brachiopods

Bryozoans

Coelenterates

Corals

Conodonts

Echinoderms

Mollusks

Protozoans

Coccoliths

Dinoflagellates

Foraminifera

Radiolaria

Silicoflagellates

Fossil Plants

Algae

Fossil Pollen

Fossil Preservation

Fossil Spores

Fossil Structure

Fossil Vertebrates Fish

Fossil Zones - Index

$$
\text { Fossils }
$$

Fouling
Freshwater Circulation

Freshwater Currents

Freshwater Catfishes

Freshwater Ecology

Fronts

Fungi

Marine Fungi nonspecific

Yeasts -nonspecific

Fungicides

Gabbro

Galapagos Islands

Gamma Radiation

Gases

Gastropods

Gates

Genetic Evolution

Geochemistry

Crystal Chemistry

Experimental Geochemistry

High Pressure Research

High Temperature

Research

Mineral Equilibria

Mineral Synthesis

Phase Relationships

Solution Chemistry

Geochemical

Investigations

Element Ratios

Isotopic Abundance Studies

Mineral - Rock

Alterations

Mineral Associations

Mineral Genesis

Trace Element

Analysis

Transfer Processes

Organic Geochemistry

Geochronology

Fossil Dating

Radioactivity Methods

Argon - Potassium

Dating

Carbon 14 Dating

Fission Track Dating

Rubidium - Strontium

Dating

Thorium Dating

Uranium Dating

Geodesy

Geodetic Mapping

Geodetic Surveys

Standard Geoid

Geologic Evolution

Geologic Faults

Rifts

Thrust Faults

Transform Faults 
Geologic Folds

Geologic History

Atmosphere History

Continent History

Glacial History

Igneous - Metamorphic History

Island Arc History

Ocean Basin History

Paleoclimatology

Paleogeography

Paleosalinity

Paleotemperature

Sea Level Changes

Sedimentary History

Tectonic History

Geologic Maps

Geologic Time

Mesozoic Era

Paleozoic Era

Precambrian

Quaternary Period

Pleistocene Epoch

Recent Epoch

Tertiary Period

Eocene Epoch

Miocene Epoch

Oligocene Epoch

Paleocene Epoch

Pliocene Epoch

Geological Exploration

Geophones

Geosynclines

Geothermal Gradient

Glacial History

Glaciers

Gold

Government

Intergovernmental

Relations

Policy Making

Granite

Gravity Studies

Crustal Movement

Detectors

Exploration Methods

Gravity Surveys

Gravimeters -general

Gravity Anomalies

Gravity Applications

Isostacy

Structural Analysis

Gravity Tectonics

Gravity Waves

Graywacke Sandstone

Great Lakes

Lake Erie

Lake Huron

Lake Michigan

Lake Ontario

Lake Superior
Greenland

Greenland Sea

Groins

Gulf Coastal Plain

Gulf of Aden

Gulf of Alaska

Gulf of California

Gulf of Guinea

Gulf of Mexico

Gulf Stream

Gulls, Plovers, Etc.

Hake

Handbooks

Harbors

Hawaii

Heat and Radiation

Transfer

Heat Balance - Budget

Heat Exchange

Heat Flows

Heavy Metals

Herbicides

Herring, Shad, and

Menhaden

Heterotrophic Bacteria

High Pressure Research

High Temperature Research

Holothuroids

Hudson Bay

Hudson River

Humboldt or Peru Current

Humidity - Water Vapor

Hydrofoil Craft

Hydrographic Surveys

Hydrozoa

Hyperbaric Chamber

Ice Studies

Ice Alteration

Ice Composition

Ice Jams

Ice Petrofabrics

Ice Properties

Ice Acoustics

Ice Electrical Properties

Ice Mechanical Properties

Ice Thermal Properties

Ice Thickness - Area

Icebergs

Icebreakers

Iceland

Igneous - Metamorphic

History

Igneous Activity -

Volcanism

Igneous Petrogenesis

Igneous Rocks

Basic - Mafic Rocks

Extrusive Igneous

Rocks 

Andesite
Basalt
Rhyolite
Japan
Java Sea
Jetties

Tuff

Intrusive Igneous

Rocks

Anorthosite

Diabase

Gabbro

Granite

Peridotite

Lava

Magma

Image Sensing Systems

Incineration

Income Analysis

Indian Ocean

Indonesia

Industrial Wastes

Industries

Atomic Plants

Electric Power Plants

Inflow

Information Systems

Infrared Radiation

Inlet - Intake

Structures

Insecticides

DDE

DDT

Dieldrin

Malathion

Insects

Int. Decade Ocean Exploration

Intelligence

Interceptor Stations

Intergovernmental Relations

International Economics

International Trade

Interstitial - Connate

Water

Intertidal - Littoral Areas

Intrusive Igneous Rocks

Invertebrate Pathology

Iodine

Iron

Island Arc History

Island Arcs

Islands

Isopods

Isostacy

Isotopic Abundance

Studies

Isotropy - Anisotropy

Jacks, Scads, and

Pompanos

Jamaica

James River
Killifishes

Kuroshio Current

L - Waves

Labrador Current

Labrador Sea

Lagoons

Lake Erie

Lake Huron

Lake Michigan

Lake Ontario

Lake Superior

Lampreys and Hagfishes

Land Bridges

Land Economics

Land Subsidence

Landfill

Landing Crafts

Laptev Sea

Larvicides

Lasers - Masers

Lava

Lead

Lefteye Flounders

Legal Studies

Law Enforcement

Legal Review

Legislation - Zoning

Legislative Levels Federal Government Local Government State Government

Pollution Taxes

Limestone - general

Lincoln Sea

Line Islands

Lithostratigraphic Unit

Lobsters

Local Government

Locks

Logistics

Long Island Sound

Mackerels and Tunas

Magma

Magmatic Differentiation

Magnesium

Magnetic Anomalies

Magnetic Intensity

Magnetic Surveys

Magnetometers

Malagasy Republic Madagascar

Malathion

Malaysia - Malaya 
Malta

Mammals

\section{Carnivors}

Cetacea

Pinnipeds

Rodents

Man in the Sea Programs

Manganese

Mantle

Mariana Islands

Marinas

Marine Bacteria

Marine Cables

Marine Fouling

Marine Fungi nonspecific

Marine Materials Undersea Materials

Marine PhotographyTelevision

Marine Pollution Agricultural Wastes Industrial Wastes Ocean Dumping Petroleum Wastes Spillage

Radioactivity

Sewage

Ship Wastes

Marine Productivity

Marine Propellers

Marine Safety

Marine Salvage

Marine Soils

Market Structure

Marketing

Marl

Marshall Islands

Mediterranean Sea Adriatic Sea

Tyrrhenian Sea

Melanesia

Melange

Mercury

Mesometeorology

Metabolism -invertebrate

Metals -general

Heavy Metals

Trace Metals

Metamorphic Petrogenesis

Metamorphic Rocks

Metasomatism

Meteorological

Condensation

Condensation Physics

Dew

Fog, Haze, Mist

Microeconomics

Microfossils

Micrometeorology

Micronesia

\author{
Microseisms - Background \\ Noise \\ Microwave Radiation \\ Military Personnel \\ Military Sciences \\ Intelligence \\ Logistics \\ Military Operations \\ Amphibious Operations \\ Antisubmarine Warfare \\ Naval Operations \\ Mineral - Rock \\ Alterations \\ Mineral Associations \\ Mineral Content -water \\ Mineral Equilibria \\ Mineral Genesis \\ Mineral Synthesis \\ Mineralogy \\ Carbonates \\ Silicates \\ Clay Minerals \\ Minnows and Carps \\ Miocene Epoch \\ Mississippi River \\ Mobile Bay \\ Mollusks \\ Cephalopods \\ Clams \\ Gastropods \\ Oysters \\ Pelecypods -other \\ Molybdenum \\ Monitoring and Baselines \\ Monocotyledons \\ Monsoons \\ Mountain Building - \\ Orogeny \\ Mountains - Massifs \\ Mudstone \\ Mullets
}

Narragansett Bay

Natural Gas

Natural Resources

Economics

Naval Operations

Naval Personnel

Naval Ships - Warships

Navigation

Nematoda

Neritic Sublittoral

Areas

Nets

New Guinea

New Hebrides Islands

New York

New Zealand

Nickel

Night Vision Detection

Systems 
Nitrogen

Ammonia

Ammonium

Nitrates

Nitrites

Nitrogen and Inert Gas Narcosis

Noncombatant Ships

North Pacific Current

North Sea

Norwegian Sea

Nuclear Devices

Nuclear Energy Conversion Fission Reactors

Nuclear Explosion

Nuclear Power Systems

Nuclear Electric Power

Nuclear Propulsion

Nucleic Acids and

Precursors

Desoxyribonucleic Acid

Ribonucleic Acid

Nutrient Pollutants

Occupations

Divers

Military Personnel

Naval Personnel

Scientists

Ocean - Lake Winds

Ocean Banks

Ocean Basin History

Ocean Basins

Ocean Bottom Sampling Devices

Ocean Circulation general

Ocean Convection Advection

Ocean Coring and Dredging

Ocean Currents

Currents -bottom

Currents -longshore -littoral

Currents -ocean

Agulhas Current

California Current

Equatorial Currents

Florida Current

Gulf Stream

Humboldt or Peru

Current

Kuroshio Current

Labrador Current

North Pacific Current

Yucatan - Gulf Loop

Current

Ocean Dumping

Ocean Energy

Ocean Engineering general
Ocean Fans

Ocean Fracture Zones

Ocean Hydrodynamics

Ocean Level Recorders

Ocean Meterological

Studies

Ocean Mining

Ocean Mixing

Ocean Motion Recorders

Ocean Optical Devices

Ocean Plains - Plateaus

Ocean Platforms

Ocean Profiles

Ocean Ridges - Hills Rises

Ocean Sediments

Mineralogy

Ocean Sediment Types

Biogenous Sediments

Cosmogenous Sediments

Marine Soils

Precipitates

Terrigenous Sediments

Turbidites

Sediment Acoustic

Properties

Sediment Biology

Sediment Chemistry

Sediment Mechanical Properties

Sediment Origin

Sediment Physical Properties

Sediment Textures Structures

Sediment Thickness Area

Sedimentation

Ocean Surface

Environment

Ocean Trenches

Ocean Waves - Currents

Oceanic - Pelagic

Environment

Oceanographic Ships

Offshore Power Plants

Oil Removal

Oligocene Epoch

Oligochaeta

Oolitic Limestone

Optical Properties, Sea Water

Optimization

Ordnance

Underwater Ordnance

Warships

Ore Deposits

Beryllium

Chromium

Copper

Gold 


\section{Iron}

Manganese

Platinum

Thorium

Tin

Uranium

Organic Deposits

Organic Geochemistry

Organics

Organism Sampling Devices

Orogenic Belts

Orographic Effects

Ostracods

Outfall Sewers

Oxygen

Oysters

\section{P - Waves}

Pacific Ocean -east

Pacific Ocean -general

Pacific Ocean -north

Pacific Ocean -south

Pacific Ocean -west

Paleo-oceanography

Paleocene Epoch

Paleoclimatology

Paleoecology

Paleogeography

Paleomagnetism

Paleontology

Classificationtaxonomy

Evolutionary Studies Adaptive Radiation Extinction Speciation

Fossil Age Studies Fossil Pollen

Fossil Preservation

Fossil Spores

Fossil Structure

Fossil Internal Structure

Shells

Microfossils

Paleoecology

Biostratigraphy -

Biofacies

Fossil Zones - Index Fossils

Population -

Paleosalinity

Distribution

Paleotemperature

Paleozoic Era

Pamlico Sound

Panama

Particle - Gas

Transfer
Particulates

Pearl River

Peat

Pelicans, Cormorants, Etc.

Peracarids

Perches

Peridotite

Periphyton

Permafrost - Frozen

Soils

Permeability

Persian Gulf

Pesticide Accumulation Rates

Environment

Accumulation Rates

Tissue Accumulation

Rates

Pesticide Analysis

Bioassay

Chemical Analysis

Metabolites from

Pesticides

Monitoring Systems

Pesticide Persistence

Pesticide Toxicity

Residues in Food

Petrogenesis

Igneous Petrogenesis

Crystallization

Magmatic

Differentiation

Metamorphic

Petrogenesis

Petrography

Petroleum

Petroleum Wastes -

Spillage

Phase Relationships

Philippine Sea

Philippines

Phosphorus

Phosphates

Phosphorus Isotopes

Physical Models

Physiological Effects

Phytoplankton

Piers

Pillow Lava

Pilot Plants

Pinnipeds

Pipelines

Piscicides

Plankton

Phytoplankton

Zooplankton

Plant Aquaculture

Plant Morphology

Plate or Block

Tectonics 


\begin{tabular}{|c|c|}
\hline Platinum & Pseudomonas -nonspecific \\
\hline Platyhelminthes & Public Health \\
\hline Trematoda & Puerto Rico \\
\hline Turbellaria & Puget Sound \\
\hline Pleistocene Epoch & Pumps \\
\hline Pliocene Epoch & \\
\hline Plumes & Quaternary Period \\
\hline Plutonium & Questionnaires \\
\hline Polar Wandering & \\
\hline Policy Making & Radar \\
\hline Pollutant Identification & Radio Telemetry \\
\hline Bioindicators & Radioactive Isotopes \\
\hline Chemical Identification & Radioactivity \\
\hline Pollutants, Path of & Radioactivity Methods \\
\hline Pollution Effects & Radioisotopes \\
\hline Ecological Effects & Radiolaria \\
\hline Environmental Effects & Radiosondes - \\
\hline Physiological Effects & Rawinsondes \\
\hline Pollution Taxes & Radium \\
\hline Polychaeta & Radon \\
\hline Polynesia & Rain \\
\hline Porgies & Rappahannock River \\
\hline Porifera & Rate of Deposition \\
\hline Porosity & Ratfishes \\
\hline Ports & Recent Epoch \\
\hline Potassium & Recreation \\
\hline Potential of Deposit & Boating \\
\hline Potomac River & Demand for Recreation \\
\hline Prawns & Economics -recreation \\
\hline Precambrian & Fishing \\
\hline Precipitates & Recreation Law \\
\hline Pressure & Safety -recreation \\
\hline Pressure, Sea Water & Seasonal Homes \\
\hline Primary Productivity & Swimming \\
\hline Probability and & Touring \\
\hline Statistics & User Patterns \\
\hline Probability & Red Sea \\
\hline Stochastic Processes & Reefs \\
\hline Statistics & Regional Economics \\
\hline Analysis of Variance & Regional Impact \\
\hline Correlation & Regression Analysis \\
\hline Regression Analysis & Remote Sensing \\
\hline Sampling & Aircraft \\
\hline Time Series Analysis & EM Radiation \\
\hline Production and Processing & Gamma Radiation \\
\hline Productivity & Infrared Radiation \\
\hline Primary Productivity & Microwave Radiation \\
\hline Secondary Productivity & Radar \\
\hline Propulsion & Visible Light \\
\hline Electrical & Lasers - Masers \\
\hline Marine & Satellites \\
\hline Nuclear & Remote Sensing Systems \\
\hline Protozoa & Reproduction \\
\hline Ciliata & Reptiles \\
\hline Cnidosporidia & Rescue Boats \\
\hline Flagellata & Residues in Foods \\
\hline Sarcodina & Resource Inventories \\
\hline Amoeba & Rhodophyta \\
\hline Foraminifera & Rhyolite \\
\hline Protozoans & Ribonucleic Acid \\
\hline
\end{tabular}


Rifts

Righteye Flounders

Ripple Marks

River Deltas

Rock and Mineral

Magnetics

\section{Rodents}

Ross Sea

Rubidium - Strontium Dating

Ruthenium

S - Waves

Safety -recreation

Saline Water Intrusion

Salinity

Salmon

Salt

Sali Domes

Salt Marches

San Andreas Rift

San Francisco Bay

Sand Dunes

Sands and Gravels

Sandstones

Sanitary Landfills

Sarcodina

Sargasso Sea

Satellites

Savannah River

Sawfishes

Scallops

Scandium

Scientists

Scorpionfishes and Rockfishes

Scotia Sea

Scouring

Scuba

Scyphozoa

Sea Basses

Sea Cliffs

Sea Floor Spreading

Sea Floor Topography

Sea Ice

Sea Level Changes

Sea Level Variations

Sea of Japan

Sea of Okhotsk

Sea Walls

Sea Water Chemistry

Chemical Reactions

Oil Removal

Radioactivity

Salinity

Sea Water Analysis

Gases

Heavy Metals

Organics

Particulates
Trace Elements

Sea Water Mass and Ocean Fronts

Sea Water Properties Acoustical Properties

Density, Sea Water

Depth, Sea Water

Electrical Properties

Electromagnetic Properties

Optical Properties, Sea Water

Pressure, Sca Water Shock Propagation Temperature, Sea Water Thermal Properties, Sea Water

Thermocline

Thermodynamics

Turbidity, Sea Water

Sea Water Sampling

Seamounts - Guyots

Seasonal Homes

Secondary Productivity

Secular Magnetic Variation

Sediment Acoustic Properties

Sediment Biology

Sediment Deposition

Rate of Deposition

Sediment Thickness

Sediment Diagenesis

Sediment Lithification

Metasomatism Calcification

Sediment Cementation

Sediment Origin

Sediment Properties

Adsorption Capacity

Exchange Capacity

Permeability

Porosity

Sediment Composition

Chemical Composition

Interstitial - Connate

Water

Organic Composition

Sediment Texture

Sediment Provenance

Studies

Sediment Thickness - Area

Sediment Transport

Transport Agents

Glaciers

Icebergs

Ocean Waves -

Currents

Turbidity Currents

Transport Direction

Transport Distance 
Transport Methods Bed Load

Dissolved Load

Suspension

Sedimentary History

Sedimentary Rocks

Carbonates

Dolomite

Limestone -general Oolitic Limestone

Chemical Sediments Bauxite

Conglomerates

Evaporites Salt

Fine-grained Clastics Claystone

Marl

Mudstone

Shale

Siltstone

Organic Deposits Bituminous Shale Peat

Sandstones

Graywacke Sandstone

Siliceous Sediments Chert

Tectogenic Clastics Breccia -general Flysch Deposits Melange

'Tuffaceous Sediments Sedimentary Structures Bedding Planes Ripple Marks Sedimentation Seiches

Seismic Instruments

Geophones

Seismographs

Strain Gauges

Tiltmeters

Seismology

Exploration Methods Seismic Mapping

Seismic Reflection

Seismic Refraction

Seismic Surveys

Generation Mechanisms

Aftershocks

Earthquakes

Explosives

Nuclear Devices

Seismic Applications

Earthquake Location

Nuclear Explosion

Structural Studies

Seismic Stations and

Networks
Seismic Wave

Characteristics

Wave Attenuation

Wave Dispersion

Wave Propagation

Wave Reflection

Wave Refraction

Wave Shape - Amplitude

Wave Velocity

Stress-strain Relations

Earth Tides

Microseisms -

Background Noise

Wave Propagation Media Isotropy - Anisotropy Plastic, Elastic, Semi-solid

Wave Types

Compressional Waves

Elastic Waves

L - Waves

P - Waves

S - Waves

Shear Waves

Surface Waves

Selenium

Severe Storms - Squalls

Sewage

Sewage System- Treatment Plant

Combined Sewers

Effluent Standards

Flushing Devices

Interceptor Stations

Sewage System Design

Sewage Treatment Plants

Small Sanitation Units

Transportation of Sewage

Shale

Shark Repellents

Sharks

Shear Waves

Shellfish Farming

Shells

Shields

Ship Assemblages \& Components

Marıne Propellers

Ship Hulls

Submarine Hulls

Ship Design -generai

Ship Instruments

Ship Motion

Ship Stability

Ship Wastes

Shipboard Computers

Ships and Boats

Anchoring and Mooring Systems

Boats and Hydrofoil 
Crafts

Airboats

Ferry Boats

Hydrofoil Craft

Rescue Boats

Tug Boats

Naval Ships - Warships

Landing Crafts

Submarines

Noncombatant Ships

Barges

Cargo and Passenger Ships

Icebreakers

Oceanographic Ships Tankers

Shoals

Shock Propagation

Shoreline Development

Shoreline Structures

Shrimps

Silicates

Siliceous Sediments

Silicoflagellates

Siltstone

Silver

Sludge Treatment and Disposal

Sludge Disposal

Incineration

Landfill

Ocean Dumping

Sludge Treatment

Dewatering

Digestion

Small Sanitation Units

Smelts

Snake River

Snow

Sodium

Soils Geology

Soil Pollution

Soil Properties

Soil Chemical Properties

Soil Moisture

Soil Salinity

Soil Types

Clay Soils

Permafrost - Frozen Soils

Submerged Soils

Solid Waste Management

Solomon Islands

Solution Chemistry

Sonar

Sounds

South China Sea

Spawning

Speciation
Spits

St. Lawrence River

Standard Geoid

State Government

Statistics

Steam

Stochastic Processes

Stocking of Fish and Shellfish

Storm Modification

Storm Surge

Strain Gauges

Strait of Gibraltar

Straits - Channels

Stratigraphy

Specific Rock Units

Lithostratigraphic Unit

Stratigraphic Section

Stratigraphic Sequence

Time - Stratigraphic

Unit

Stratigraphic Correlation

Stratigraphic Facies

Subsurface Stratigraphy

Streams

Deposition Features

River Deltas

Stream Morphology

Stress Corrosion

Stress-strain Relations

Strontium

Strontium Istotopes

Structural Analysis

Structural Studies

Sub-bottom Structure

Submarine and Diving

Medicine

Submarine Canyons

Submarine Hulls

Submarines

Submerged Soils

Submergent Shorelines

Subsurface Stratigraphy

Sulfur

Sulfates

Sulfides

Surface Waves

Surfperches

Suspension

Susquehanna River

Swamps - Marshes

Swimming

Synoptic Weather

Observations

Tags

Taiwan Strait

Tankers

Tectogenic Clastics

Tectonic Features 
Basins -sedimentarystructural

Continents

Cratons - Platforms

Crust

Earth Interior

Core

Discontinuities

Mantle

Geosynclines

Island Arcs

Land Bridges

Mountains - Massifs

Ocean Basins

Orogenic Belts

Salt Domes

Shields

Volcanoes

Tectonic History

Tectonics

Continental Drift

Deformation

Epeirogenic Movement isotasy

Gravity Tectonics

Igneous Activity -

Volcanism

Land Subsidence

Mountain Building Orogeny

Plate or Block Tectonics

Sea Floor Spreading

Tectogenesis

Telemetry

Biotelemetry

Radio Telemetry

Temperature, Sea Water

Terrigenous Sediments

Tertiary Period

Tetrodotoxin

Thermal Degradation

Thermal Pollution

Thermal Properties,

$$
\text { Sea Water }
$$

Thermocline

Thermodynamics

Thorium

Thorium Dating

Thrust Faults

Thunderstorms

Tidal Power Sources

Tidal Streams

Tides

Tidewater Areas

Tiltmeters

Time - Stratigraphic

$$
\text { Unit }
$$

Time Series Analysis

Tin

Titanium

Tcrnadoes - Waterspouts
Touring

Toxic Substances

Algal Toxins

Animal Toxins

Bacterial Endotoxins

Bacterial Exotoxins

Cytotoxic Agents

Tetrodotoxin

Trace Element Analysis

Trace Elements

Trace Metals

Tracers

Dyes

Radioisotopes

Tracheophyta

Transducers

Transform Faults

Transport Direction

Transport Distance

Transport Methods

Transportation

Transportation of Sewage

Trematoda

Trinidad

Tropical Cyclones Hurricanes

Trout

Tsunami

Tuff

Tuffaceous Sediments

Tug Boats

Tuna

Turbellaria

Turbidites

Turbidity - water

Turbidity Currents

Turbines

Gas

Hydraulic

Steam

Turbulence - ocean

Tyrrhenian Sea

Under-water Construction

Undersea Materials

Undersea Power Plants

Underwater Communication

Underwater Ordnance

Upper Atmosphere Physics

Uranium

Uranium Dating

Urochordata

Vaccines

Vanadium

Venezuela

Venoms - invertebrate

Venoms - vertebrate

Vertebrate Pathology

Vertebrate Sound

Production 
Virgin Islands

Viruses, Animal

Viruses, Plant

Visible Light

Volcanics

Fissure Eruptions

Pillow Lava

Volcanoes

Cinder Cones

Volcanic Vents

Volcanoes

Wake Island

Wakes

Warships

Waste Water Treatment

Activated Carbon

Aeration

Chemical Oxidation

Chlorination

Degradation

Denitrification

Disinfection

Filtration

Water Balance - Budget

Wave Action

Wave Attenuation

Wave Dispersion

Wave Propagation

Wave Propagation Media

Wave Reflection

Wave Refraction

Wave Shape - Amplitude

Wave Types

Wave Velocity

Wave-built Terraces

Wave-cut Terraces

Waves - internal

Waves - ocean

Weather Forecasting
Weather Modification

Clouds - Precipitation

Fog - Mist Dissipation

Storm Modification

Weather Sensing

Aircraft

Automatic Stations Networks

Balloons

Radar

Radiosondes -

Rawinsondes

Satellites

Towers

Weathering - geologic

Weddell Sea

Weirs

Welding

Wetlands

Whitefish and Cisco

Willamette River

Winches

Wind

Wind - Water Interaction

Wind Direction

Wind Profiles

Wind Shear

Wind Velocity

Wisconsin

Wocd Preservatives

Creosote

Yeasts - nonspecific

York River

Yucatan - Gulf Loop

Current

Zinc

Zirconium

Zoogeography

Zooplankton 


